University of New Hampshire

University of New Hampshire Scholars' Repository

6-20-1992

\title{
A model of nitrous oxide evolution from soil driven by rainfall events: 1 . Model structure and sensitivity
}

Changsheng $\mathrm{Li}$

University of New Hampshire - Main Campus

Steve Frolking

University of New Hampshire - Main Campus, steve.frolking@unh.edu

Tod A. Frolking

Denison University

Follow this and additional works at: https://scholars.unh.edu/earthsci_facpub

\section{Recommended Citation}

Li, C., S. Frolking, and T. A. Frolking (1992), A model of nitrous oxide evolution from soil driven by rainfall events: 1. Model structure and sensitivity, J. Geophys. Res., 97(D9), 9759-9776, doi:10.1029/92JD00509.

This Article is brought to you for free and open access by the Earth Sciences at University of New Hampshire Scholars' Repository. It has been accepted for inclusion in Earth Sciences Scholarship by an authorized administrator of University of New Hampshire Scholars' Repository. For more information, please contact Scholarly.Communication@unh.edu. 


\title{
A Model of Nitrous Oxide Evolution From Soil Driven by Rainfall Events: 1. Model Structure and Sensitivity
}

\author{
Changsheng LI \\ The Bruce Company, Washington, D. C. \\ STEVE FrolKING \\ Institute for the Srudy of Earth, Oceans and Space, University of New Hampshire, Durham
}

ToD A. FrolkING

Department of Geology and Geography, Denison University, Granville, Ohio

\begin{abstract}
This paper describes a rain-event driven, process-oriented simulation model, DNDC, for the evolution of nitrous oxide $\left(\mathrm{N}_{2} \mathrm{O}\right)$, carbon dioxide $\left(\mathrm{CO}_{2}\right)$, and dinitrogen $\left(\mathrm{N}_{2}\right)$ from agricultural soils. The model consists of three submodels: thermal-hydraulic, decomposition, and denitrification. Basic climate data drive the model to produce dynamic soil temperature and moisture profiles and shifts of aerobic-anaerobic conditions. Additional input data include soil texture and biochemical properties as well as agricultural practices. Between rainfall events the decomposition of organic matter and other oxidation reactions (including nitrification) dominate, and the levels of total organic carbon, soluble carbon, and nitrate change continuously. During rainfall events, denitrification dominates and produces $\mathrm{N}_{2} \mathrm{O}$ and $\mathrm{N}_{2}$. Daily emissions of $\mathrm{N}_{2} \mathrm{O}$ and $\mathrm{N}_{2}$ are computed during each rainfall event and cumulative emissions of the gases are determined by including nitrification $\mathrm{N}_{2} \mathrm{O}$ emissions as well. Sensitivity analyses reveal that rainfall patterns strongly influence $\mathrm{N}_{2} \mathrm{O}$ emissions from soils but that soluble carbon and nitrate can be limiting factors for $\mathrm{N}_{2} \mathrm{O}$ evolution during denitrification. During a year sensitivity simulation, variations in temperature, precipitation, organic $\mathrm{C}$, clay content, and $\mathrm{pH}$ had significant effects on denitrification rates and $\mathrm{N}_{2} \mathrm{O}$ emissions. The responses of DNDC to changes of external parameters are consistent with field and experimental results reported in the literature.
\end{abstract}

\section{INTRODUCTION}

This paper reports the structure of a computer model for assessing nitrous oxide $\left(\mathrm{N}_{2} \mathrm{O}\right)$ emissions from agricultural soils. The current atmospheric $\mathrm{N}_{2} \mathrm{O}$ concentration is about $8 \%$ greater than in the preindustrial era and is increasing at a rate of about $0.8 \mathrm{ppb}(0.25 \%)$ per year [Weiss, 1981; Elkins and Rossen, 1989]. Ice core measurements indicate that the concentration of atmospheric $\mathrm{N}_{2} \mathrm{O}$ started to increase around the period 1700-1800 [Pearman et al., 1986; Khalil and Rasmussen, 1988; Etheridge et al., 1988], with a rapid concentration increase beginning about 1950 [Intergovernmental Panel on Climate Change (PPCC), 1990].

Nitrous oxide is a nonreactive, long-lived, radiatively active trace gas in the troposphere. Currently, $\mathrm{N}_{2} \mathrm{O}$ contributes approximately $5 \%$ of the global warming potential in greenhouse effect assessments [Rodhe, 1990]. The major sink for $\mathrm{N}_{2} \mathrm{O}$ is photolysis in the stratosphere, leading to nitrogen oxide products which influence levels of stratospheric ozone [Crutzen, 1970]. Because of these important links to both climate and atmospheric chemistry the causes for the increasing atmospheric $\mathrm{N}_{2} \mathrm{O}$ concentration are of great interest. International discussions are already in progress to develop approaches for regulating the sources of $\mathrm{N}_{2} \mathrm{O}$. Unfortunately, the large uncertainties present in estimates of sources of $\mathrm{N}_{2} \mathrm{O}$ preclude the development of any detailed strategies for their mitigation.

A recent assessment of $\mathrm{N}_{2} \mathrm{O}$ sources by the IPCC indicates

Copyright 1992 by the American Geophysical Union.

Paper number 92JD00509.

0148-0227/92/92JD-00509\$05.00 that soils and agriculture fertilizers are important sources of $\mathrm{N}_{2} \mathrm{O}$ [IPCC, 1990]. Nitrous oxide is primarily derived as an intermediate product of microbial denitrification and nitrification processes in soils (for reviews see Delwiche [1981]; Sahrawat and Keeney [1986]; Seiler and Conrad [1987]). While many laboratory and field investigations of $\mathrm{N}_{2} \mathrm{O}$ production rates by soil microbes have been conducted, quantification of global $\mathrm{N}_{2} \mathrm{O}$ emissions from soils has proven extremely difficult because of the heterogeneity of soil chemical, physical, and biological properties which interact to determine production and emission rates. In particular, variations in soil moisture, soil texture, and carbon and nitrogen substrates for microbial nitrification and denitrification are critical to determining $\mathrm{N}_{2} \mathrm{O}$ emissions [e.g., Leffelaar and Wessel, 1988; Tanji, 1982; Frissel and Van Veen, 1981; Batlach and Tiedje, 1981; Cho et al., 1979].

Numerous simulation models have been developed to estimate denitrification rates and processes in soils (Table 1). The early models [e.g., Focht, 1974; Mehran and Tanji, 1974] were studies of denitrification kinetics at the laboratory-incubation scale. Several of the more recent models [e.g., Grant, 1991; Johnsson et al., 1991; Clay et al., 1985; and Molina et al., 1983] were designed to predict total $\mathbf{N}$ losses from soils on field scales, but not specifically $\mathrm{N}_{2} \mathrm{O}$ fluxes to the atmosphere, and thus model only total denitrification $\left(\mathrm{N}_{2} \mathrm{O}+\mathrm{N}_{2}\right)$ in combination with various decomposition processes. Others, which focus more closely on $\mathrm{N}_{2} \mathrm{O}$ by modeling the various steps of denitrification and microscopic processes such as substrate diffusion [e.g., Leffelaar and Wessel, 1988; McConnaughey and Bouldin, 1985], do not incorporate field scale variables such as temperature, moisture, and carbon substrate availability. Van Veen and Frissel [1979] model both decomposition and denitrification processes, substrate diffusion and availability, 
TABLE 1. Denitrification/Decomposition Models

\begin{tabular}{|c|c|}
\hline Reference & Model description \\
\hline Focht [1974] & $\begin{array}{l}\text { Denitrification kinetics independent of nitrate concentration, linear function of } p \mathrm{H} \text { and } \\
\text { oxygen status, exponential function of temperature. } \mathrm{N}_{2} \mathrm{O}: \mathrm{N}_{2} \text { ratio depends only on } \\
\text { aeration and } \mathrm{pH} \text {. }\end{array}$ \\
\hline $\begin{array}{l}\text { Mehran and Tanji } \\
\text { [1974] }\end{array}$ & $\begin{array}{l}\text { All nitrogen transformations (nitrification, denitrification, mineralization, immobilization, } \\
\mathrm{N} \text { plant uptake, and } \mathrm{NH}_{4}{ }^{+} \text {exchange) are calculated for a single pool of each } \mathrm{N} \text { species } \\
\text { by first-order kinetics. No treatment of decomposition and carbon substrates. }\end{array}$ \\
\hline $\begin{array}{l}\text { Van Veen and } \\
\text { Frissel [1979] }\end{array}$ & $\begin{array}{l}\text { Microorganisms are central to the dynamics of } \mathrm{N} \text { (nitrification, denitrification, } \\
\text { mineralization and immobilization); } \mathrm{C} \text { and } \mathrm{N} \text { cycling are interdependent. Decay of } \\
\text { various } \mathrm{C} \text { and } \mathrm{N} \text { pools by first-order or Monod kinetics; multiplicative reduction factors } \\
\text { are used to reduce reaction rates under suboptimal environments. Denitrification model } \\
\text { considers diffusion of } \mathrm{O}_{2} \text { and } \mathrm{NO}_{3}^{-} \text {away from air-filled pores; only considers total } \\
\text { denitrification. }\end{array}$ \\
\hline $\begin{array}{l}\text { Molina es al. [1983] } \\
\text { and Clay er al. } \\
\text { [1985] }\end{array}$ & $\begin{array}{l}\text { Computes short-term dynamics of decomposition of residues and two soil carbon pools, } \\
\text { each containing a labile and resistant component. } \mathrm{N} \text { availability, which limits } \\
\text { decomposition rates, results from the processes of residue decomposition, mineralization, } \\
\text { immobilization, nitrification, and denitrification. Total denitrification fixed at a constant } \\
\text { fraction of decomposition. Clay et al. model couples this with layered soil, soil } \\
\text { temperature and water flow, plant growth, and tillage for field simulations. }\end{array}$ \\
\hline $\begin{array}{l}\text { McConnaughey and } \\
\text { Bouldin [1985] }\end{array}$ & $\begin{array}{l}\text { Model of saturated soil. Anaerobic volume and transient solute diffusion to and away from } \\
\text { zones of } \mathrm{N} \text { reduction are modeled. The model considers the reduction sequence: } \mathrm{NO}_{3} \\
\rightarrow \mathrm{NO}_{2} \rightarrow \mathrm{N}_{2} \mathrm{O} \rightarrow \mathrm{N}_{2} ; \text { transient diffusion of } \mathrm{NO}_{3}, \mathrm{NO}_{2} ; \mathrm{N}_{2} \mathrm{O} \text {, and } \mathrm{N}_{2} \text { allowed throughout } \\
\text { the saturated soil, while reduction of the nitrogenous species occurs only in the anaerobic } \\
\text { region. No treatment of carbon substrate limitations. }\end{array}$ \\
\hline $\begin{array}{l}\text { Mosier and Parton } \\
\text { [1985] and Parton } \\
\text { et al. [1988] }\end{array}$ & $\begin{array}{l}\text { Nitrification and denitrification of urea-treated and control shortgrass-prairie soils. Nitrous } \\
\text { oxide production controlled by soil temperature, moisture, ammonium and nitrate levels. }\end{array}$ \\
\hline $\begin{array}{l}\text { Lefjelaar and } \\
\text { Wessel [1988] }\end{array}$ & $\begin{array}{l}\text { Microbial respiration and denitrification are described for a homogeneous soil layer, in } \\
\text { which no transport processes occur. Major processes are growth and maintenance of } \\
\text { denitrifier biomass and reduction of } \mathrm{NO}_{3}^{-} \text {to } \mathrm{N}_{2} \text {, via } \mathrm{NO}_{2}^{-} \text {and } \mathrm{N}_{2} \mathrm{O} \text {. Growth of biomass } \\
\text { is calculated by a first-order rate equation in which the relative growth rate is described } \\
\text { by a double Monod equation consisting of rate-limiting factors for } \mathrm{C} \text { and nitrogenous } \\
\text { substrates. The Pirt equation is used to calculate the consumption rates of substrates. }\end{array}$ \\
\hline Grant [1991] & $\begin{array}{l}\text { Total denitrification }\left(\mathrm{N}_{2} \mathrm{O}+\mathrm{N}_{2}\right) \text { for agroecosystems. Couples detailed treatment of oxygen } \\
\text { and substrate diffusion to anserobic microsites with layered soil model of } \mathrm{C} \text { and } \mathrm{N} \\
\text { dynamics in decomposition (first-order kinetics). Denitrification is controlled by } \\
\text { temperature and oxygen concentration. }\end{array}$ \\
\hline $\begin{array}{l}\text { Johnsson et al. } \\
\text { [1991] }\end{array}$ & $\begin{array}{l}\text { Field scale model of total denitrification }\left(\mathrm{N}_{2} \mathrm{O}+\mathrm{N}_{2}\right) \text {, a function of potential rate, soil } \\
\text { lemperature, soil oxygen status, and nitrate availability. Potential rate, a function of soil } \\
\text { type and cropping system. Dynamic soil temperature and moisture determined from soil } \\
\text { type and surface. Carbon substrate assumed unlimiting. }\end{array}$ \\
\hline This model & $\begin{array}{l}\text { Field scale model of decomposition and denitrification, as controlled by soil climate. Daily } \\
\text { decomposition of several soil carbon pools by first-order kinetics; rain-event-driven } \\
\text { denitrification via growth and maintenance of individual denitrifiers. Agricultural } \\
\text { practices, soil properties, and climate control the model. No diffusion of substrates but } \\
\text { macroscopic flow with soil water. }\end{array}$ \\
\hline
\end{tabular}

and various inorganic $\mathrm{N}$ transformations but do not treat denitrification with enough detail to separate $\mathrm{N}_{2} \mathrm{O}$ from $\mathrm{N}_{2}$ production. The model of Parton et al., [1988; also see Mosier and Parton, 1985] focuses on the relative importance of denitrification and nitrification to $\mathrm{N}_{2} \mathrm{O}$ fluxes in grasslands and takes into account daily to seasonal variations in soil conditions but does not contain enough detail concerning substrate dynamics to be easily generalizable to a variety of agricultural ecosystems. None of these models are able to predict daily or seasonal $\mathrm{N}_{2} \mathrm{O}$ emissions from field soils using readily available input data. In particular, none of these models can be used to study the impacts of various agricultural practices on nitrous oxide emissions.

To better understand and quantify soil sources of $\mathrm{N}_{2} \mathrm{O}$, we have developed a model that couples decomposition and denitrification processes, as influenced by the soil environment, to predict emissions from agricultural soils (Figure 1). The model runs on a personal computer and uses commonly available climate, soil, and agricultural practice data as input. Our model is directed to two applications: (1) investigation of the interactions of fundamental climatic, pedologic, agronomic, and microbiological variables which influence the production and emission of nitrous oxide from agricultural soils and (2) development of an improved quantitative assessment of the large-scale emissions of nitrous oxide from agroecosystems in the United States and globally.

\section{MODEL}

\subsection{Model Framework}

Emissions of nitrous oxide and dinitrogen $\left(\mathrm{N}_{2}\right)$ from soils are not temporally continuous. On the basis of field monitoring and experimentation, pulses of $\mathrm{N}_{2} \mathrm{O}$ and $\mathrm{N}_{2}$ from soils are observed to follow rainfall or irrigation events [Roulier and Fetter, 1973; Duxbury and McConnaughey, 1986; Mosier et al., 1986; Sexstone et al., 1985; Goodroad 


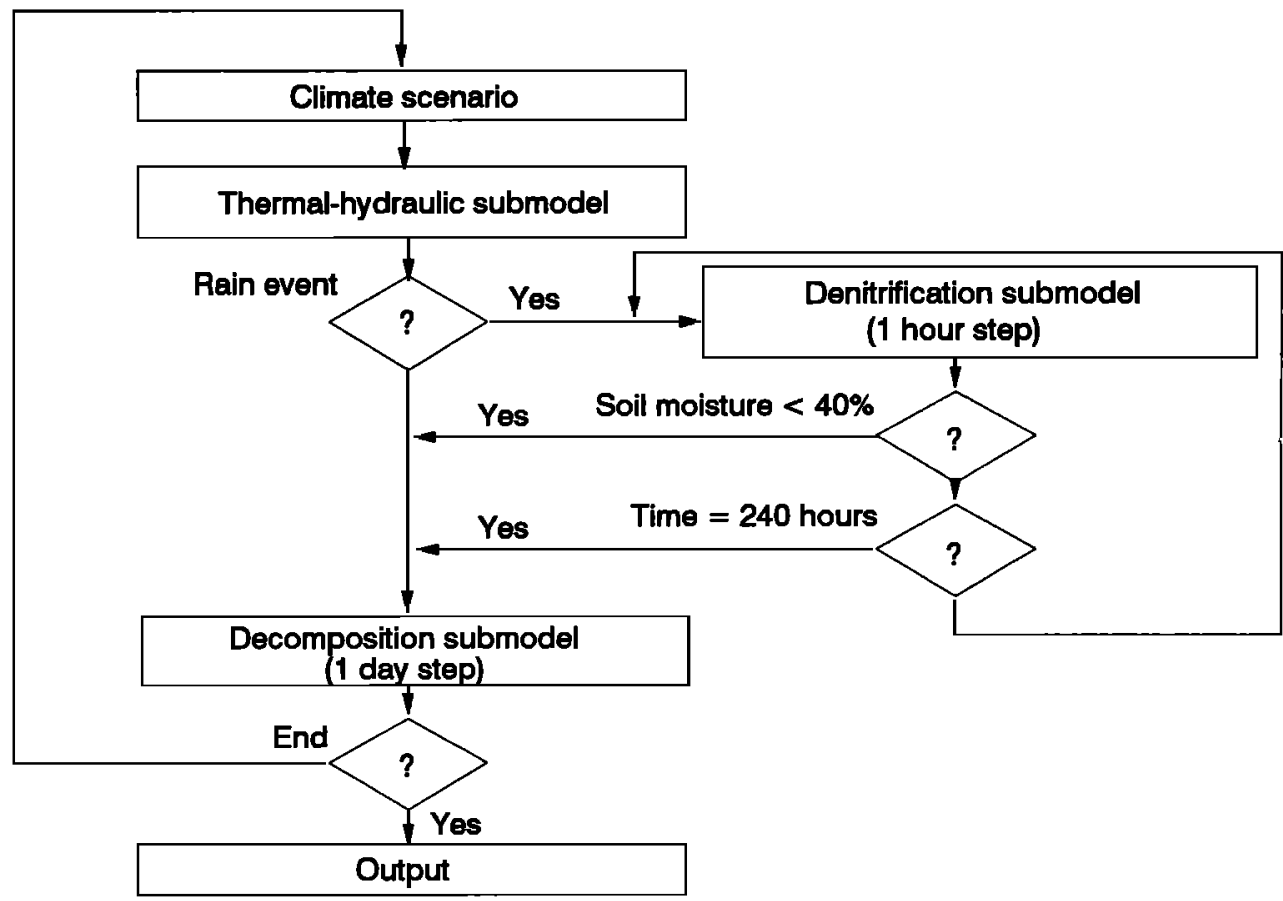

Fig. 1. Structure of DNDC model. Flow chart showing the relationship of the three submodels of thermal-hydraulic flow, decomposition, and denitrification. The thermal-hydraulic flow submodel reads daily climate data from an existing climate scenario file and calculates temperature and moisture profiles. The denitrification model starts with a rain event and continues until the soil moisture (water-filled porosity) decreases to $40 \%$. The decomposition submodel runs continuously.

and Keeney, 1984]. The connection between emissions of $\mathrm{N}_{2} \mathrm{O}$ and $\mathrm{N}_{2}$ and rain events can be explained primarily through the biochemical processes related to microbial activities in soils.

Denitrification occurs under oxygen-deficient conditions (e.g., in wet soils following rain events), when denitrifying bacteria utilize nitrate (rather than oxygen) as an electron acceptor [e.g., Knowles, 1981; Sahrawat and Keeney, 1986; Davidson, 1991]. Dissolved carbon compounds (referred to below as soluble carbon) in the soil solution are the major electron donors during denitrification as carbon is converted to $\mathrm{CO}_{2}$. Under oxic conditions, these denitrifying bacteria along with many other bacteria decompose organic residues and microbial biomass to produce soluble carbon compounds and ammonium. These two processes along with ammonia volatilization, nitrification, adsorption, and plant uptake interact to control the substrate pools for microbial activity and gaseous emissions of $\mathrm{N}_{2} \mathrm{O}, \mathrm{N}_{2}$, and $\mathrm{CO}_{2}$.

Because of the substantial difference in $\mathrm{N}_{2} \mathrm{O}$ emissions between wet and dry soils, a season or year can be modeled effectively as a sequence of wet and dry periods. Soil temperature and moisture are two key factors controlling the rates of both decomposition and denitrification during these periods. Soil thermal-hydraulic flux, aerobic decomposition, and denitrification submodels of DNDC (DeNitrification and DeComposition) work together in simulating $\mathrm{N}_{2} \mathrm{O}$ and $\mathrm{N}_{2}$ emissions with a 1-day time step (1 hour during rain events) (Figure 1). In addition, the model calculates concentrations of nitrate, nitrite, ammonium, organic residues, microbial biomass, humads, and soluble carbon in the soil profile, as well as mineralization rates of $\mathbf{C}$ and $\mathbf{N}$, nitrate leaching, and emissions of carbon dioxide and ammonia from the soil.
Model equations and parameters are presented in the appendices.

\subsection{Submodel of Thermal-Hydraulic Flows}

A one-dimensional soil heat flux and moisture flow model (Figure 2) has been designed to calculate average hourly and daily soil temperature and moisture profiles. The modeled soil is divided into a series of horizontal layers. Each layer is assumed to have a uniform temperature and moisture content, assigned to a point at the middle of the layer. For each time step, water fluxes and heat flows between layers are determined by the gradients of soil water potential and soil temperature, respectively. All values are determined per unit area in the horizontal plane. These gradient-driven equations are numerically modeled by explicit finite difference equations (see Table 2 for thermal-hydraulic model equations). Typical vertical spatial resolution is $5 \mathrm{~cm}$ and time steps are generally about $\mathbf{3 0} \mathbf{~ m i n}$. Rainwater is added or evapotranspired water removed at the beginning of each time step, before gradient-driven fluxes are determined. Water flow out of the bottom of the modeled profile (typically 50 cm deep) is driven by gravity drainage only [Van Bavel and Lascano, 1980]. Heat flux into/out of the bottom layer is determined by the gradient between the bottom layer temperature and the annual mean air temperature imposed at $500 \mathrm{~cm}$ depth. To run the simulation with a minimum amount of meteorological input data, the heat flux at the soil surface is simplified to a gradient driven flux between the soil surface, which is assigned a temperature equal to the mean daily air temperature, and the top soil layer temperature at a depth of several centimeters. 
Data from climate scenario

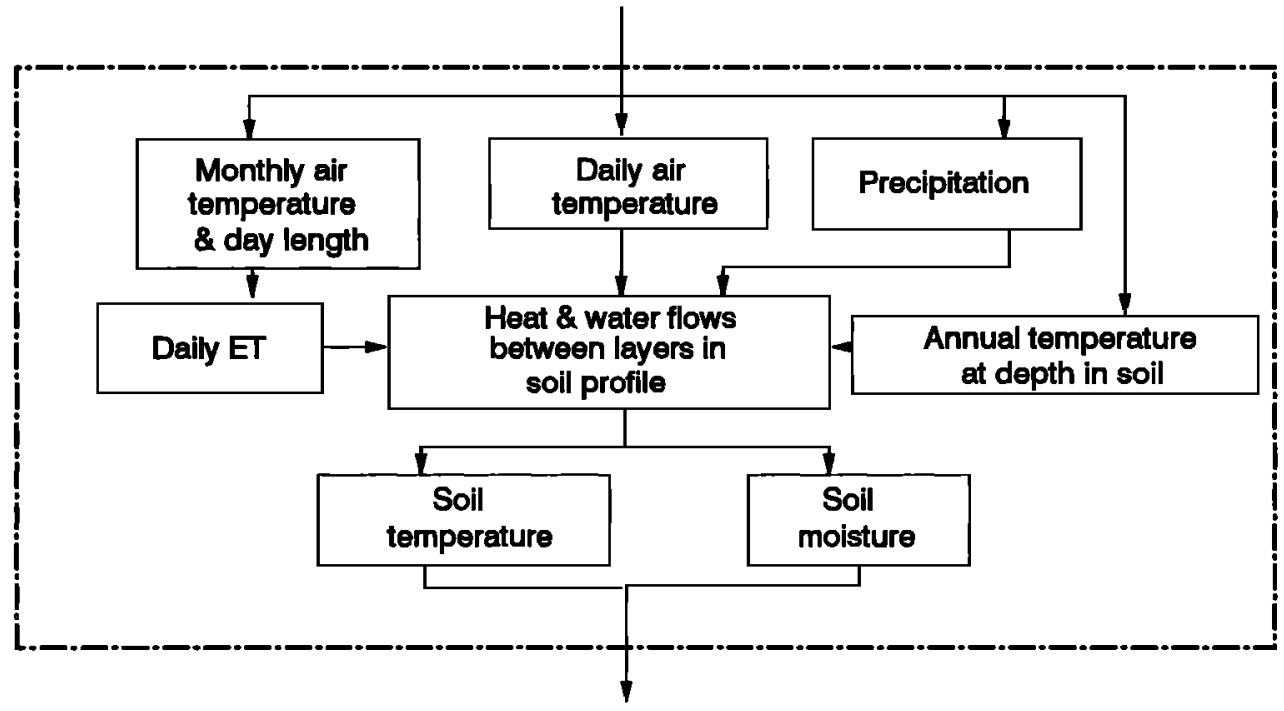

To submodels of decomposition and denitrification

Fig. 2. The one-dimensional thermal-hydraulic submodel simulates soil heat flux and moisture flow and calculates hourly and daily average soil temperature and moisture profiles. The heat fluxes and moisture flows are driven by diffusion gradients (and gravity for water flow) for a layered soil profile. Soil texture controls soil hydraulic properties.

The moisture boundary condition at the soil surface has precipitation/irrigation and evapotranspiration components. Precipitation (or irrigation) events are prescribed input events. Since the goal of the DNDC model is to predict seasonal or annual $\mathrm{N}_{2} \mathrm{O}$ emissions, the precise timing of precipitation events is not important. We assume that all rain events start at midnight, are of constant intensity (throughout an individual storm but potentially varying intensity from one storm to the next), and of variable duration. At the beginning of each time step, the rainfall for that time step

TABLE. 2. Thermal-Hydraulic Submodel Equations

\begin{tabular}{|c|c|}
\hline Equation & Description \\
\hline 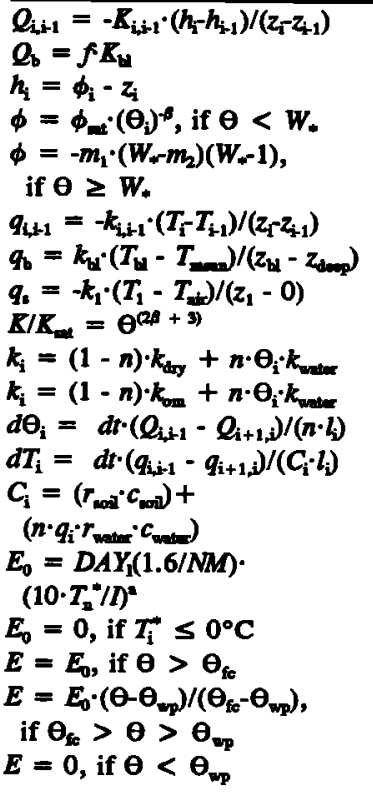 & $\begin{array}{l}\text { Soil heat flux (layer } i-1 \rightarrow \text { layer } i) \\
\text { Soil heat flux at bottom of profile } \\
\text { Soil heat flux at surface } \\
\text { Soil relative hydraulic conductivity } \\
\text { Soil thermal conductivity } \\
\text { Water conservation } \\
\text { Energy conservation } \\
\text { Soil layer volumetric heat capacity }\end{array}$ \\
\hline
\end{tabular}

saturates the soil, layer by layer, to the depth that it can fill. Any residual rainwater (not needed to fill a layer) is uniformly distributed in the next deeper layer. At present we assume there is no surface runoff, and although evaporation of intercepted water can account for a significant fraction of rainwater, particularly for vegetation with a thick canopy [Bras, 1990], we do not model intercepted water.

Evapotranspiration (ET) is calculated as monthly average values using the Thornthwaite formula, in which potential ET is determined by monthly mean air temperature and then adjusted for daylight length relative to 12 hours [Dunne and Leopold, 1978]. If soil moisture is limiting then actual ET is less than potential ET. We follow Sellers [1965] in having actual ET decrease linearly from potential ET to zero as the soil water potential drops from $-0.033 \mathrm{MPa}$ (field capacity) to $-1.5 \mathrm{MPa}$ (wilting point). DNDC assumes that ET

TABLE 3. Soil Type and Properties

\begin{tabular}{|c|c|c|c|c|c|c|c|c|}
\hline Soil Type & $\underset{\%}{\text { Clay }}$ & $\begin{array}{l}\mathrm{n} \\
\boldsymbol{\psi}\end{array}$ & $\underset{\mathrm{cm} / \mathrm{min}}{\bar{R}}$ & $\boldsymbol{\beta}$ & $\phi_{\text {mat }}$ & $\begin{array}{l}\theta_{f e} \\
\%\end{array}$ & $\begin{array}{l}\theta_{w p} \\
\%\end{array}$ & $\stackrel{c}{\mathrm{~J} / \mathrm{kgK}}$ \\
\hline Sand & 3 & 39.5 & 1.056 & 4.05 & 3.50 & 32 & 12 & 2000 \\
\hline Loamy sand & 6 & 41.0 & 0.938 & 4.38 & 1.78 & 30 & 12 & 2000 \\
\hline Sandy loam & 9 & 43.5 & 0.208 & 4.90 & 7.18 & 45 & 21 & 2000 \\
\hline Silty loam & 14 & 48.5 & 0.043 & 5.30 & 56.6 & 46 & 34 & 2000 \\
\hline Loam & 19 & 45.1 & 0.042 & 5.39 & 14.6 & 55 & 27 & 2000 \\
\hline Snd cl loam & 28 & 42.0 & 0.038 & 7.12 & 8.63 & 59 & 35 & 2000 \\
\hline Slt cl loam & 34 & 47.7 & 0.010 & 7.75 & 14.6 & 66 & 40 & 2000 \\
\hline Clay loam & 34 & 47.6 & 0.015 & 8.52 & 36.1 & 76 & 49 & 2000 \\
\hline Sandy clay & 43 & 42.6 & 0.013 & 10.4 & 6.16 & 68 & 47 & 2000 \\
\hline Silty clay & 49 & 49.2 & 0.006 & 10.4 & 17.4 & 75 & 52 & 2000 \\
\hline Clay & 63 & 48.2 & 0.008 & 11.4 & 18.6 & 77 & 55 & 2000 \\
\hline Organic & 6 & 80.0 & 0.010 & 7.75 & 14.6 & 66 & 40 & 2500 \\
\hline
\end{tabular}

See notation section for definitions of variables. Source: Specific heats (c), de Vries [1975]. $\theta_{f f}$ and $\theta_{\text {ep }}$ calculated (see text). All other values, Clapp and Hornberger [1978]. Note: $K_{\text {m }}$ and $\beta$ values for organic soil are not reported by Clapp and Hormberger [1978]; we chose the values for silty tlay loam. 
removes water from the top $20 \mathrm{~cm}$ of the soil; root density is assumed uniform over the top $20 \mathrm{~cm}$, and root growth dynamics are modeled. For each layer, actual ET withdrawal depends on that layer's water content.

DNDC characterizes soil physical properties by soil texture (see Table 3 for soil parameters), following the work of Clapp and Hornberger [1978]. The soil thermal conductivity depends on soil water content and on the type of soil (mineral or organic). The soil layer net thermal conductivity for a given moisture content is an average of the thermal conductivities of the solid phase and water, weighted by their relative volumes in the soil.

Soil water tension and unsaturated hydraulic conductivity are strong functions of the soil water content. For each of these, DNDC uses the exponential formulation of Clapp and Hornberger [1978], with representative parameters for each of 12 soil textures.

\subsection{Submodel of Decomposition}

When soil is in an aerobic state, decomposition and other oxidation reactions, including nitrification, are the dominant microbial processes. Assimilation of inorganic carbon and nitrogen into microbial biomass also occurs with the decomposition of residues, microbial biomass and humads (materials partially stabilized by humification and adsorption, McGill et al., [1981]). During decomposition and assimilation, organic $\mathrm{C}$, soluble $\mathrm{C}$, ammonium, and nitrate are produced and may accumulate. The levels of these substrates depend on the balance between the rates of mineralization (transformation of organic $\mathbf{C}$ or $\mathbf{N}$ to inorganic
C or $\mathbf{N}$ ), assimilation, and loss (plant uptake, sorption, or volatilization).

The decomposition submodel follows that of Molina et al., [1983], with three active carbon pools for the decomposition sequence (Figure 3). The soil profile is divided into horizontal layers with a typical thickness of $2 \mathrm{~cm}$. Each layer is assumed to have uniform properties (temperature, moisture, substrate and microbe concentrations, etc.) and all decomposition calculations are performed layer by layer. The decomposition submodel runs in a daily time step for every day of the simulation. When a rain event occurs, the decomposition submodel pauses, and the denitrification submodel runs until the top $20 \mathrm{~cm}$ of the soil has an average water content of less than $40 \%$ of porosity [Bremner and Shaw, 1958a, b; Nommik, 1956], or for a maximum of 10 days by which time very little denitrification occurs in the model due to depletion of substrates. The decomposition submodel then resumes with the rainy day and the average soil climate for that rainy day.

Pools of organic matter. Decomposition (as modeled in DNDC) can simultaneously occur in three organic matter pools: decomposable residues (mainly plant residues), microbial biomass, and humads; each pool has a labile and resistant component (Figure 3). The passive organic phase, or stable humus, is assumed not to interact with the active phase during the short time span of the model (about 1 year). We define soil organic carbon as the sum of microbial biomass, humads, and humus. During the decomposition process each component decomposes independently [Hunt, 1977; Jenkinson, 1977].

Decomposition rates. The resistant and labile carbon pools

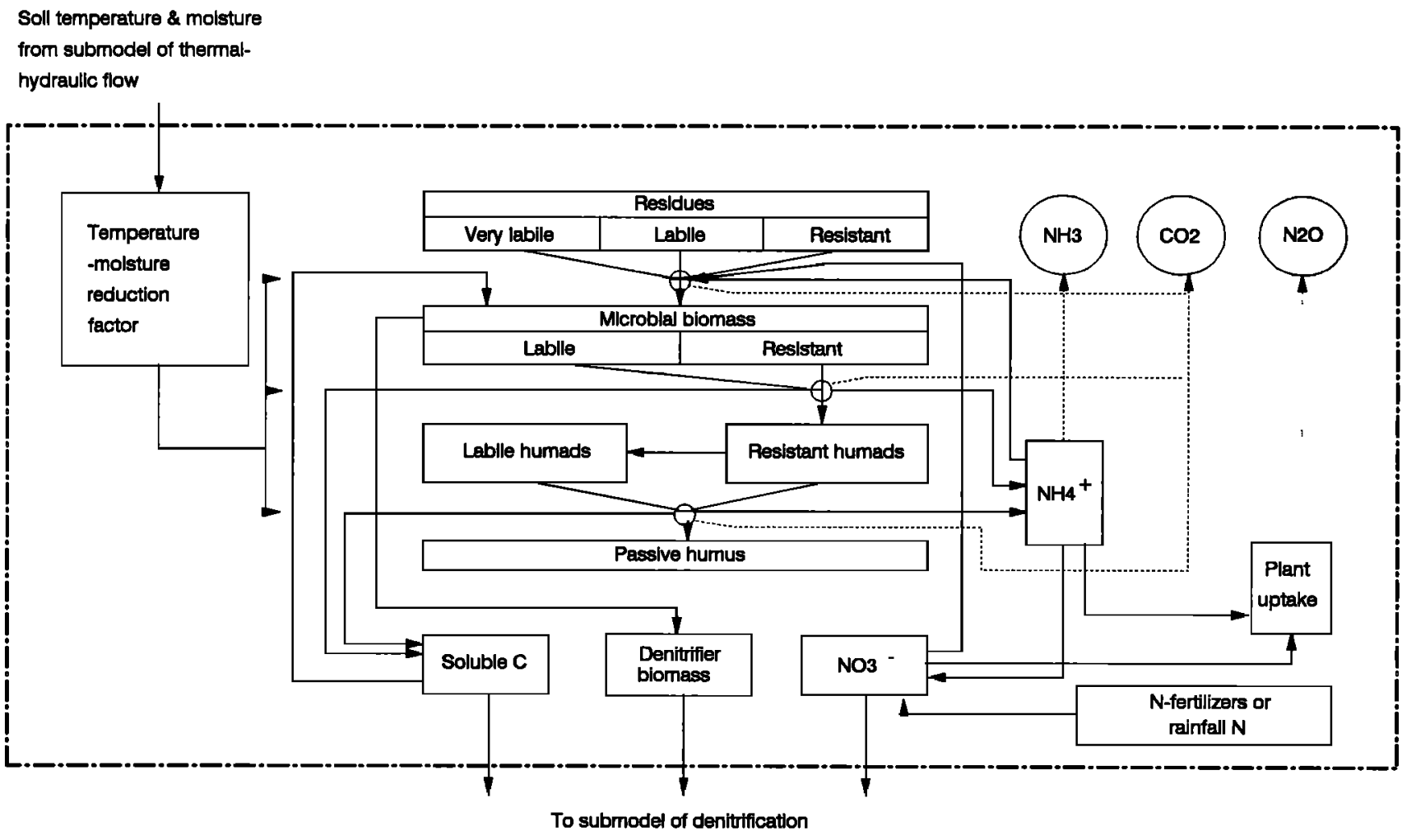

Fig. 3. In the decomposition submodel, organic matter consists of four pools: residue, microbial biomass, humads, and passive humus. Nonhumus pools contain labile and resistant components. Components have different temperature- and moisture-dependent decomposition rates. Pools of soluble carbon, microbial biomass, and nitrate are shared with the denitrification submodel. 
TABLE 4. Decomposition Submodel Bquations

\begin{tabular}{|c|c|}
\hline Equation & Description \\
\hline 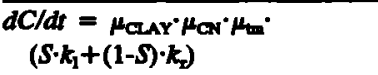 & Carbon pool decomposition rate \\
\hline$R_{c}=B /$ eff $=B+$ COP & $\begin{array}{l}\text { Biomass production and } \mathrm{CO}_{2} \text { evolution } \\
\text { during residue decomposition }\end{array}$ \\
\hline $\begin{array}{l}F T X N H 4=[0.41-0.47 \cdot \\
\log (N H 4)] \cdot\left(C L A Y / C L A Y_{m}\right)\end{array}$ & Ammonium adsorption \\
\hline 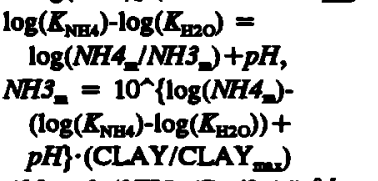 & $\begin{array}{l}\text { Transformation of ammonia to } \\
\text { ammonium }\end{array}$ \\
\hline$A M=2 \cdot(N H 3) \cdot(D \cdot t / 3.14)^{0.5}$ & Ammonia volatilization \\
\hline $\begin{array}{c}d N N O=N H 4(t) \cdot\left[1-\exp \left(-R_{35}\right.\right. \\
\left.\left.\mu_{t, 2} \cdot d t\right)\right]^{\cdot} \mu_{3,1} \\
N 2 O=(0.0014 \cdot N H 4 / 30.0) \\
(0.54+0.51 \cdot T) / 15.8\end{array}$ & $\mathrm{~N}_{2} \mathrm{O}$ emitted during nitrification \\
\hline
\end{tabular}

(residues, microbial biomass, and humads) decompose via first-order kinetics. This formulation has been widely used to estimate mineralization potentials of soils and yield results consistent with data from incubation studies [Molina et al., 1983; Stanford and Smith, 1972; Smith et al., 1980; Deans et al., 1983; El-Haris et al., 1983; Deans et al., 1986]. Carbon:nitrogen ratios differ significantly between residues and microbial biomass, therefore the actual decomposition rates for residues are affected by the availability of nitrogen in the soil (see Table 4 and Table 5 for decomposition equations and parameters, respectively). A reduction factor is introduced into the decomposition equation to reflect the limitations set by available N [Molina et al., 1983].

For residues the specific decomposition rate (SDR) for each component was deduced from the production of carbon dioxide $\left(\mathrm{CO}_{2}\right)$ during decomposition in laboratory incubation experiments [Gilmour et al., 1985]. These laboratory values of SDR are higher than field results [e.g., Terry et al., 1981]. Laboratory results are based on relatively pure organic fractions, which do not exist in the field. In this study therefore we use the laboratory results, but we multiply the SDRs by a single, fixed reduction factor $(0.025)$ to simulate all field situations. The reduction factor was determined from comparison of model runs with field-measured $\mathrm{CO}_{2}$ emission rates on agricultural sites in Costa Rica and Germany [Sauerbeck and Gonzalez, 1977].

TABLE 5. Decomposition Submodel Parameters

\begin{tabular}{|c|c|c|c|c|}
\hline Pool & Component & $\begin{array}{l}\text { Initial } \\
\text { Fraction }\end{array}$ & $\mathbf{C} / \mathbf{N}$ & $\begin{array}{l}\text { SDR } \\
1 / \text { day }\end{array}$ \\
\hline \multirow[t]{3}{*}{ Residue } & very labile & $0.08^{\circ}$ & $2.35^{\circ}$ & $0.074^{*}$ \\
\hline & labile & $0.32^{\star}$ & $20^{\circ}$ & $0.074^{e}$ \\
\hline & resistant & $0.60^{\circ}$ & $20^{\circ}$ & $0.02^{4}$ \\
\hline \multirow[t]{2}{*}{ Biomass } & labile & 0.9 & $8^{c}$ & $0.33^{b}$ \\
\hline & resistant & $0.1^{\bullet}$ & $8^{e}$ & $0.04^{b}$ \\
\hline \multirow[t]{2}{*}{ Humads } & labile & $0.16^{b}$ & 84 & $0.16^{b}$ \\
\hline & resistant & $0.84^{b}$ & 8 & $0.006^{b}$ \\
\hline
\end{tabular}

'Gilmour et al. [1985].

'Molina es al. [1983].

'Krapp et al. [1983].

'Stevenson [1982].
The clay content of soils also affects the decomposition of organic matter; clays can adsorb organic $\mathbf{C}$ and shelter it from decomposition [Bouwman, 1990]. DNDC models this shielding effect as a multiplicative factor $(0.35$ to $1.67 ; 1.0$ for loam) that decreases the decomposition rate for increasing clay contents.

Production and decomposition of microbial biomass and humads. As the residue pools decompose, the carbon released is either respired as $\mathrm{CO}_{2}$ or incorporated into microbial biomass (Figure 3). DNDC first determines the amount of $\mathrm{CO}_{2}$ produced. From this and a microbial efficiency value, DNDC calculates the amount of carbon incorporated into microbial biomass, with $90 \%$ going into labile biomass and 10\% going into resistant biomass [Gilmour et al., 1985]. Microbial efficiency, defined here as the ratio of $\mathbf{C}$ assimilated into microbial biomass to residue $\mathbf{C}$ released by decomposition, has been reported to vary between $20 \%$ and 60\% [Paul and Juma, 1981; Paul and Van Veen, 1978; Chichester et al., 1975; Molina et al., 1983; Gilmour et al., 1985]. In soils amended with easily decomposable organic material (e.g., animal wastes), the microbial population buildup is high [Griffin and Laine, 1983], while in unamended soils the fraction of decomposed $C$ used for microbial growth is relatively small [Jansson and Persson, 1982]. This study adopts efficiency values of $60 \%$ for amended soil and $20 \%$ for unamended soil.

As microbes die and their biomass decomposes (Figure 3), $20 \%$ of the carbon is transfered to $\mathrm{CO}_{2}, 60 \%$ of the carbon is reincorporated into new microbial biomass, and $20 \%$ is transferred to the resistant humads pool [Molina et al., 1983; Gilmour et al., 1985]. The resistant humads pool can lose carbon through decomposition or via soil disturbance (see discussion of tillage effects below). As each humads pool decomposes, $40 \%$ of the carbon is transferred to the stable humus pool, $40 \%$ of the carbon is converted to $\mathrm{CO}_{2}$ and $20 \%$ is reincorporated into microbial biomass [Molina et al., 1983 ].

The soluble carbon pool (Figure 3) consists of the carbon from microbial biomass decomposition (60\%) and humads decomposition (20\%) that is recycled into microbial biomass. Thus it is not actually a carbon pool but rather an indicator of the daily rate of decomposition. When a rain event occurs, the denitrification model initiates its calculations using this soluble carbon pool as the amount of soluble carbon available in the soil.

Effect of temperature and moisture on decomposition. DNDC models the effects of soil temperature [Nyhan, 1976] and water content [Clay et al., 1985] on microbial activity with reduction factors which retard the decomposition rate for nonoptimum conditions (Figures $4 a$ and $4 b$ ). These relationships between microbial activity and both temperature and moisture are generally consistent with the results of other studies [e.g., Bremner and Shaw, 1958a, b; Witkamp, 1966; Alexander, 1971; Myers and McGarity, 1971; Jager and Bruins, 1974; Wildung et al., 1975]. Since the reduction factor represents the combined effect of temperature and moisture, it is taken as the product of the two factors.

Nitrogen behavior during decomposition. During the decomposition of organic matter in soils, nitrogen behavior is simulated in the following manner: (1) when organic $C$ is oxidized to $\mathrm{CO}_{2}$, the associated $\mathrm{N}$ is transformed to ammonium $\left(\mathrm{NH}_{4}^{+}\right)$; (2) $\mathrm{NH}_{4}^{+}$can be nitrified to nitrate or transferred to ammonia and volatilized to the air; and (3) 

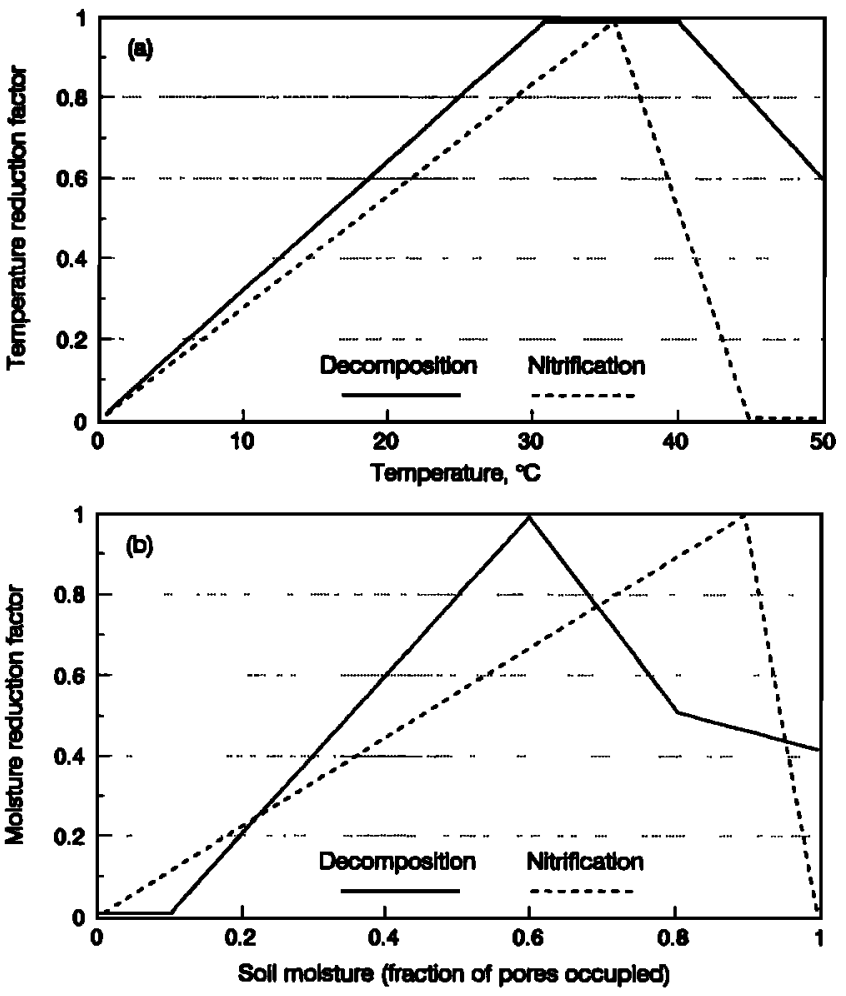

Fig. 4. Soil climate reduction factors. The dimensionless (a) temperature dependence and (b) moisture dependence reduction factors for the decomposition process (solid line) and the nitrification process (dotted line).

when organic $\mathbf{C}$ transfers from one pool to another, surpluses or deficits of available $\mathrm{N}$ can occur because of the differences in $C: N$ ratios among different pools. If excess $N$ is created (carbon transfer from a lower $C: N$ pool to a higher $C: N$ pool), the excess $\mathbf{N}$ is moved to the inorganic $\mathbf{N}$ pool. If a nitrogen deficit occurs (carbon transfer from a higher $C: N$ pool to a lower $\mathbf{C}: \mathbf{N}$ pool), the necessary nitrogen is removed from the inorganic $\mathbf{N}$ pool; if the pool does not contain enough $\mathbf{N}$ to satisfy the demand, the $\mathbf{C}$ transfer is reduced to an allowable level. Thus the inorganic $\mathbf{N}$ pool collects $\mathbf{N}$ (as $\mathrm{NH}_{4}{ }^{+}$and $\mathrm{NO}_{3}{ }^{-}$) from the oxidation processes and supplies $\mathrm{NH}_{4}^{+}$and $\mathrm{NO}_{3}^{-}$for assimilation, nitrification, volatilization, denitrification, or plant uptake.

Uptake of nitrate and ammonium by plants. As plants grow they take up nitrogen in the form of nitrate or ammonium. On the basis of average rates of accumulation of nitrogen in aboveground crops [Olson, 1978; Olson and Kurtz, 1982], the estimated daily uptake of $\mathbf{N}$ is calculated from crop type and seeding date as input data. Plant nitrogen comes from $\mathrm{NO}_{3}^{-}$and $\mathrm{NH}_{4}^{+}$pools, based on their relative concentrations.

Behavior of ammonium. The major factors affecting adsorption of $\mathrm{NH}_{4}{ }^{+}$by clay and organic matter in soil are the total available adsorption sites and the $\mathrm{NH}_{4}{ }^{+}$concentration in the soil liquid phase [Nommik, 1965]. Since there is often a rough positive correlation between clay and organic carbon content in soils [Jones, 1972; Food and Agriculture Organization (FAO)/UNESCO, 1971-1981], clay content is chosen as an index of adsorption sites. Transformation of ammonium to ammonia is influenced by soil $\mathrm{pH}$, temperature, buffer capacity [Freney et al., 1981]. Volatilization of ammonia is related to the $\mathrm{NH}_{3}$ concentration in the liquid phase and a diffusion coefficient [Gardner, 1965].

Effect of fertilization. Application of $\mathbf{N}$ fertilizers can change the $\mathbf{N}$-cycle dynamics in the soil. Common $\mathbf{N}$ fertilizers include ammonium, nitrate, urea, and anhydrous ammonia. Nitrate fertilizer directly enters the $\mathrm{NO}_{3}^{-}$pool. Urea and ammonium fertilizers transfer to nitrate through hydrolysis and/or nitrification. Anhydrous ammonia affects soil pH and transfers to ammonium.

Effect of tillage. Tillage can change the decomposition rates and the distribution of organic matter in the soil profile by physically mixing the soil and by increasing oxygen activity [Tivy, 1990]. In DNDC, when a soil is tilled there are two effects: (1) all pools of organic matter are redistributed as uniform concentrations down to the tillage depth, and (2) a fraction of the resistant humads pool is transferred into labile humads. This more rapid decomposition effect is modeled as decreasing with time after tillage. The initial transfer is $16 \%$ of the resistant humads pool, with subsequent transfers of $12 \%, 8 \%$, and $4 \%$ following the next three rain events [Sorensen, 1975]. Note that without tillage there is no flow of carbon to the labile humads pool (Figure 3).

Nitrification. Under aerobic conditions, $\mathrm{NH}_{4}^{+}$can be oxidized to $\mathrm{NO}_{2}{ }^{-}$and $\mathrm{NO}_{3}{ }^{-}$by ammonium oxidizers [McGill et al., 1981; Van Veen and Frissel, 1979]. This process is called nitrification. According to a study by Watts and Hanks [1978] the potential rate of nitrification in the surface soil is related to the available $\mathrm{NH}_{4}{ }^{+}$, soil temperature, and soil moisture. DNDC models the rate as a function of these factors with an optimal rate at $35^{\circ} \mathrm{C}$ and soil pore moisture content of $90 \%$ (Hadas et al., [1986]; Figures $4 a$ and $4 b$ ).

During nitrification the amount of $\mathrm{N}_{2} \mathrm{O}$ emitted in soils correlates with the amount of nitrifiable $\mathrm{N}$ in soils [Parton et al., 1988, Bremner and Blackmer, 1978]. In DNDC we regard ammonium as the direct factor controlling $\mathrm{N}_{2} \mathrm{O}$ emissions under aerobic conditions. On the basis of the data of Bremner and Blackmer [1981], $\mathrm{N}_{2} \mathrm{O}$ emissions from nitrification processes are modeled as a function of soil temperature and soil ammonium concentration.

\subsection{Submodel of Denitrification}

Leffelaar and Wessel [1988] present a detailed model of denitrification processes in laboratory incubations of soil samples. Denitrification follows the reduction sequence $\left(\mathrm{NO}_{3}^{-} \rightarrow \mathrm{NO}_{2}^{-} \rightarrow \mathrm{N}_{2} \mathrm{O} \rightarrow \mathrm{N}_{2}\right.$ ) with the rate of each process depending on the availability of the particular $\mathrm{N}$ oxide and all processes competing for available C. DNDC uses a similar model structure for denitrification (Figure 5), activating this submodel at every rainfall event. The soil profile is divided into horizontal layers with a typical thickness of $2 \mathrm{~cm}$. Each layer is assumed to have uniform properties (temperature, moisture, substrate and microbe concentrations, etc.) and all denitrification calculations are performed layer by layer. In DNDC a rainfall event is defined as the time period from rainfall initiation to the time when relative moisture (fraction of water-occupied pores) decreases to $40 \%$. In the model, denitrifying conditions (low oxygen availability) occur immediately upon saturation with water. During the denitrification calculation we assume that only denitrifiers are active.

Relative growth and death rates of denitrifiers. Almost all 


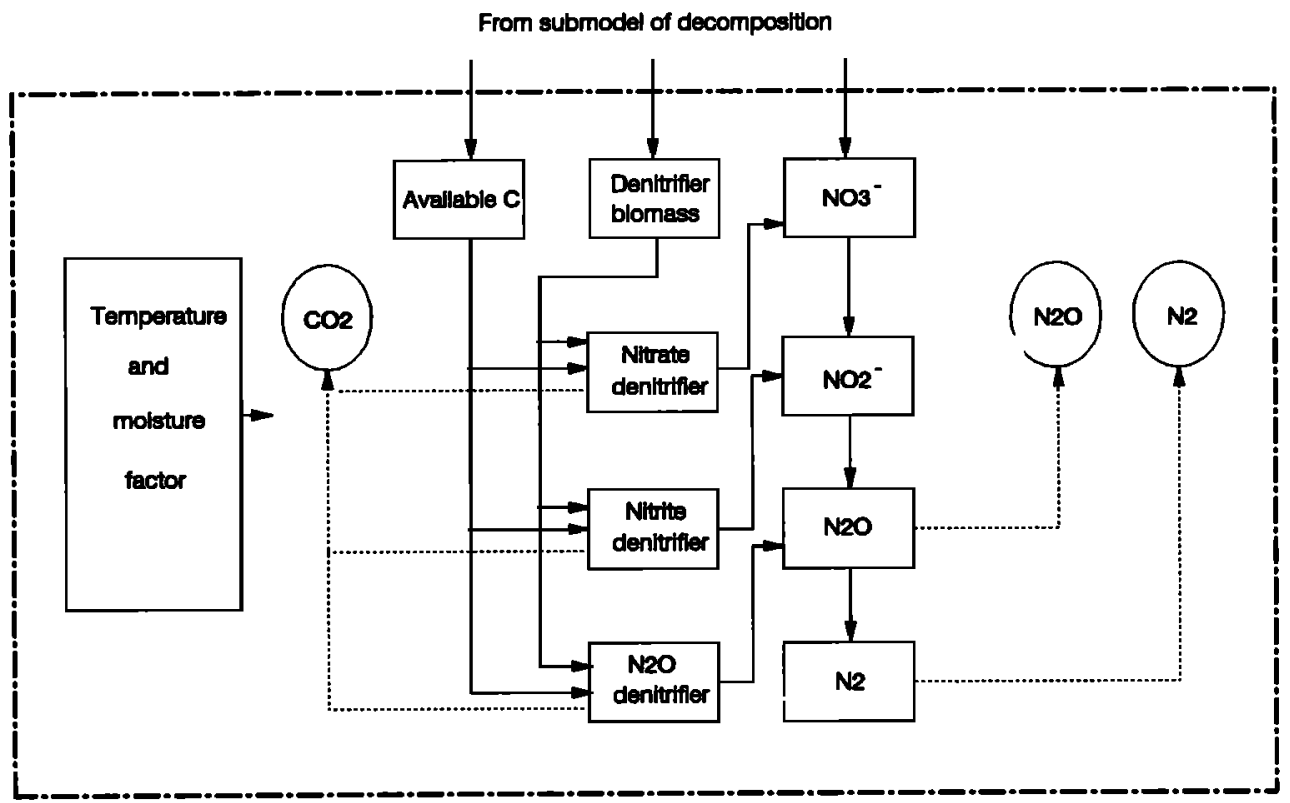

Fig. 5. In the denitrification submodel, initial denitrifier biomass is a fixed fraction of total microbial biomass in the decomposition submodel. Soluble carbon and nitrate from decomposition are utilized by denitrifiers as electron donor and acceptor, respectively. The evolution rates of nitrite, nitrous oxide and dinitrogen are controlled by the growth rates of the various denitrifiers, which depend on soil moisture, temperature, $\mathrm{pH}$, soluble carbon, and nitrate.

denitrifiers are capable of anaerobic growth only in the presence of $\mathrm{NO}_{3}^{-}, \mathrm{NO}_{2}^{-}$, or $\mathrm{N}_{2} \mathrm{O}$. The growth rates of denitrifiers directly affect the reduction rates of these nitrogenous oxides. Denitrifiers are assumed to become active at the onset of a rainfall event. Tiedje [1978] and Smith and Tiedje [1979] reported a short lag period (1 to 10 hours) before denitrification began following soil wetting. Ignoring this lag time probably causes DNDC to model $\mathrm{N}_{2} \mathrm{O}$ and $\mathrm{N}_{2}$ production earlier than in field situations.

The growth rates of the bacteria are taken to be

TABLE 6. Denitrification Submodel Equations

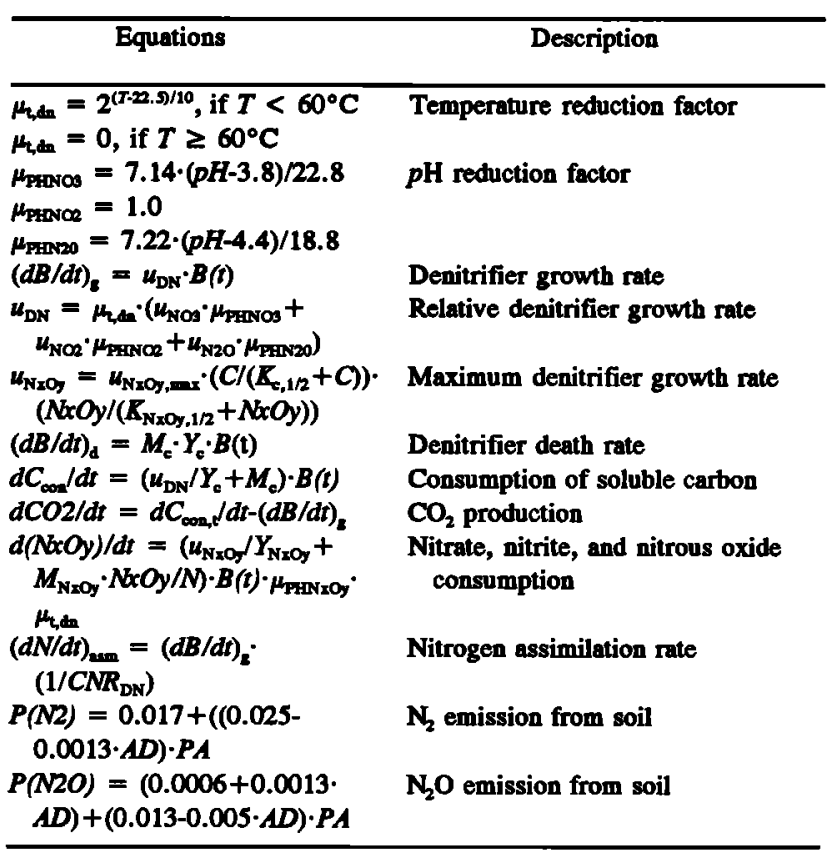

proportional to their respective biomass (Van Veen and Frissel [1981]; see Table 6 and Table 7 for denitrification submodel equations and parameters, respectively). Relative growth rates, which depend on the concentrations of carbon and electron acceptors (N oxides), are calculated with doubleMonod kinetics, a simple function describing multiplenutrient-dependent Michaelis-Menten-type growth [Bader, 1978]. Following Leffelaar and Wessel [1988] we assume that the relative growth rates for denitrifiers with different substrates are independent; competition among the bacteria takes place via the common soluble carbon substrate.

The denitrifier death rate is modeled as proportional to denitrifier biomass. The $\mathbf{C}$ and $\mathbf{N}$ from dead cells are added to the pools of immobilized $\mathbf{C}$ and $\mathbf{N}$ and no longer participate in the dynamic processes [Leffelaar and Wessel, 1988]. Since denitrifier biomass is a very small fraction of total soil biomass, this represents an insignificant loss of $\mathrm{C}$ and $\mathrm{N}$ from the soil system.

Effect of soil environment on denitrification. The effect of soil $\mathrm{pH}$ on denitrification has been measured by many researchers [Mueller et al., 1980; Klemedtsoon et al., 1978; Burford and Bremner, 1975; Stanford et al., 1975; Khan and Moore, 1968; Wijler and Delwiche, 1954]. On the basis of experimental studies, $\mathrm{pH}$ affects nitrate and nitrous oxide transformation rates differently such that at low $\mathrm{pH}(<5)$, most denitrification stops at $\mathrm{N}_{2} \mathrm{O}$ [Focht, 1974; Leffelaar and Wessel, 1988]. In general, total denitrification decreases as soil $\mathrm{pH}$ decreases.

An exponential relationship between denitrification rate and temperature has been observed [e.g., Focht, 1974; Nommik, 1956; Dawson and Murphy, 1972]. According to Bailey and Beauchamp [1973] and Nommik [1956] the rate of denitrification is very temperature dependent in the $10^{\circ}-35^{\circ} \mathrm{C}$ range, with a $Q_{10}$ near 2.0 [Stanford et al., 1975; Knowles, 1981]. The rate continues to increase at higher temperatures, reaching a maximum at $60^{\circ}-75^{\circ} \mathrm{C}$ and then falling to zero 
TABLE 7. Denitrification Parameters

\begin{tabular}{|c|c|c|c|c|}
\hline Parameter & Definition & Value & Unit & Source \\
\hline 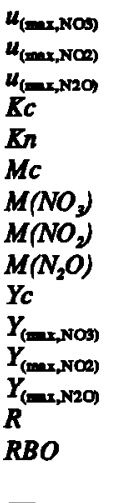 & $\begin{array}{l}\text { Maximum growth rate of } \mathrm{NO}_{3}^{-} \text {denitrifier } \\
\text { Maximum growth rate of } \mathrm{NO}_{2}^{-} \text {denitrifier } \\
\text { Maximum growth rate of } \mathrm{N}_{2} \mathrm{O} \text { denitrifier } \\
\text { Half-saturation value of soluble carbon } \\
\text { Half-saturation value of } \mathrm{N} \text {-oxides } \\
\text { Maintenance coefficient on } \mathrm{C} \\
\text { Maintenance coefficient on nitrate } \\
\text { Maintenance coefficient on nitrite } \\
\text { Maintenance coefficient on } \mathrm{N}_{2} \mathrm{O} \\
\text { Maximum growth rate on soluble C } \\
\text { Maximum growth rate on nitrate } \\
\text { Maximum growth rate on nitrite } \\
\text { Maximum growth rate on } \mathrm{N}_{2} \mathrm{O} \\
\text { C/N ratio in denitrifiers } \\
\text { Ratio of microbial to total organic C }\end{array}$ & $\begin{array}{l}0.67 \\
0.67 \\
0.34 \\
0.017 \\
0.083 \\
0.0076 \\
0.09 \\
0.035 \\
0.079 \\
0.503 \\
0.401 \\
0.428 \\
0.151 \\
3.45 \\
0.01- \\
0.025\end{array}$ & $\begin{array}{l}1 / \text { hour } \\
1 / \mathrm{hour} \\
1 / \mathrm{hour} \\
\mathrm{kg} \mathrm{C} / \mathrm{m}^{3} \\
\mathrm{~kg} \mathrm{~N} / \mathrm{m}^{3} \\
\mathrm{~kg} \mathrm{C} / \mathrm{kg} / \mathrm{h} \\
\mathrm{kg} \mathrm{N} / \mathrm{kg} / \mathrm{h} \\
\mathrm{kg} \mathrm{N} / \mathrm{kg} / \mathrm{h} \\
\mathrm{kg} \mathrm{N} / \mathrm{kg} / \mathrm{h} \\
\mathrm{kg} \mathrm{C} / \mathrm{kg} \mathrm{C} \\
\mathrm{kg} \mathrm{C} / \mathrm{kg} \mathrm{N} \\
\mathrm{kg} \mathrm{C} / \mathrm{kg} \mathrm{N} \\
\mathrm{kg} \mathrm{C} / \mathrm{kg} \mathrm{N}\end{array}$ & $\begin{array}{l}\text { Hartel and Alexander [1987] } \\
\text { Hartel and Alexander [1987] } \\
\text { Hartel and Alexander [1987] } \\
\text { Shah and Coulman [1978] } \\
\text { Shah and Coulman [1978] } \\
\text { Van Verseveld et al. [1977] } \\
\text { Van Verseveld et al. [1977] } \\
\text { Van Verseveld et al. [1977] } \\
\text { Van Verseveld et al. [1977] } \\
\text { Van Verseveld et al. [1977] } \\
\text { Van Verseveld et al. [1977] } \\
\text { Van Verseveld et al. [1977] } \\
\text { Van Verseveld et al. [1977] } \\
\text { Van Verseveld and Stouthamer [1978] } \\
\text { Woldendorp [1981] and Anderson and } \\
\text { Domsch [1989] }\end{array}$ \\
\hline FD & Ratio of denitrifiers to microbial biomass & $\begin{array}{c}0.001- \\
0.5\end{array}$ & & Focht and Verstraete [1977] \\
\hline
\end{tabular}

[Keeney et al., 1979; Bremner and Shaw, 1958b]. At lower temperatures the denitrification rate decreases but is measurable down to $0^{\circ}-5^{\circ} \mathrm{C}$ [Bailey and Beauchamp, 1973; Bremner and Shaw, 1958b; Smid and Beauchamp, 1976]. Since most parameters adopted in this study are based on a standard temperature of $22.5^{\circ} \mathrm{C}$, the temperature effect factor is a standard exponential function equal to 1.0 at $22.5^{\circ} \mathrm{C}\left(Q_{10}\right.$ $=2)$. This one temperature factor is applied to the activities of $\mathrm{NO}_{3}^{-}, \mathrm{NO}_{2}^{-}$, and $\mathrm{N}_{2} \mathrm{O}$ denitrifiers.

Consumption of $\mathrm{C}, \mathrm{NO}_{3}^{-}, \mathrm{NO}_{2}^{-}$, and $\mathrm{N}_{2} \mathrm{O}$; Production of $\mathrm{CO}_{2}$. Soluble carbon can be used by bacteria as the basic material for cell synthesis and energy [Pirt, 1965]. The consumption rate of soluble carbon depends on the biomass, relative growth rate, and maintenance coefficients of the denitrifier populations. Carbon dioxide production is calculated as the difference between the total amount of carbon consumed and the amount used for cell synthesis.

Nitrate, nitrite, and nitrous oxide consumption are calculated with Pirt's equation. The maintenance coefficients must be multiplied by the relative presence of each electron acceptor in the water phase $(\mathrm{NxOy} / \mathrm{N})$, because data reported in the literature are for maintenance sufficient to support the entire denitrifier biomass, $\mathrm{NO}_{3}^{-}$denitrifier $+\mathrm{NO}_{2}^{-}$denitrifier $+\mathrm{N}_{2} \mathrm{O}$ denitrifier [Leffelaar and Wessel, 1988].

On the basis of the growth rates of denitrifiers and the $C: N$ ratio in the bacteria the assimilation of $\mathbf{N}$ during denitrification can be calculated. A C:N ratio (by weight) of 3.45 is used, based on the chemical composition of denitrifiers $\left(\mathrm{C}_{6} \mathrm{H}_{10.8} \mathrm{~N}_{1.5} \mathrm{O}_{2.9}\right)$, in accordance with data reported for Paracoccus denitrificans [Verseveld and Stouthamer, 1978].

Diffusion of $\mathrm{N}_{2} \mathrm{O}$ and $\mathrm{N}_{2}$ in soil. During rainfall events, when a soil layer is initially saturated with water, diffusion of $\mathrm{N}_{2} \mathrm{O}$ and $\mathrm{N}_{2}$ is neglected because of the low diffusion rates in soil water. According to the results of Letey et al., [1980] the daily emissions of $\mathrm{N}_{2} \mathrm{O}$ or $\mathrm{N}_{2}$, as a percentage of total $\mathrm{N}_{2} \mathrm{O}$ or $\mathrm{N}_{2}$, are related to the adsorption coefficients of the gases in soils and to the air-filled porosity of the soil. Based on their data, $\mathrm{N}_{2}$ and $\mathrm{N}_{2} \mathrm{O}$ emissions are modeled as functions of both adsorption coefficient and air-filled porosity. Since denitrification is concentrated in the surface soil in most cases, the effect of soil depth on diffusion is not considered in this model. These emission factors are not gradient driven and will undoubtedly create some artifacts in the shape of the denitrification $\mathrm{N}_{2} \mathrm{O}$ pulse.

\section{MODEL OPERATION}

Climate, soil physical and chemical properties, and land use are important factors which govern $\mathrm{N}_{2} \mathrm{O}$-production processes in soils. These factors comprise the input for the DNDC Model (Table 8). Daily mean air temperature and daily rainfall/irrigation data are compiled into a climate scenario. Irrigation events are considered equivalent to rainfall events. Additional input data include soil properties such as texture, initial temperature and moisture, density, $\mathrm{pH}$, initial organic residue content, organic carbon and nitrate concentrations, crop type, tillage practices, amendments, and fertilizer applications.

Since denitrification mostly occurs within the top $30-75 \mathrm{~cm}$ for most mineral soils [Gilliam et al., 1978; Rolston et al., 1976; Khan and Moore, 1968], a typical total thickness of a modeled soil profile is $50 \mathrm{~cm}$. Initially, the top $10 \mathrm{~cm}$ of soil is assumed to be chemically uniform. Below this level, the concentrations of organic residues, organic $\mathrm{C}$ and $\mathrm{NO}_{3}^{-}$ decrease exponentially with depth $(50 \%$ every $10 \mathrm{~cm})$. During rainfall events, dissolved $\mathrm{NO}_{3}{ }^{-}$and $\mathrm{NO}_{2}^{-}$move down to deeper layers with the water flux. In the model, $\mathrm{N}_{2} \mathrm{O}$ and $\mathbf{N}_{2}$ do not move with the water flux. The thermal-hydraulic

TABLE 8. Model Input Parameters

\begin{tabular}{|c|c|}
\hline Category & Parameter \\
\hline Climate & $\begin{array}{l}\text { Mean daily air temperature; rainfall events (timing, } \\
\text { intensity, duration); } \mathrm{NO}_{3}^{-} \text {concentration in rainwater. }\end{array}$ \\
\hline Soil & $\begin{array}{l}\text { Type (texture); density; } p \mathrm{H} \text {; initial residue, organic carbon, } \\
\text { nitrate, and ammonium contents; initial soil temperature } \\
\text { and moisture. }\end{array}$ \\
\hline $\begin{array}{l}\text { Land use } \\
\text { Agronomic } \\
\text { practices }\end{array}$ & $\begin{array}{l}\text { Crop type; seeding and harvest time. } \\
\text { Tillage (timing, intensity); fertilizer application (species, } \\
\text { amount, timing, depth); manure amendment (type, } \\
\text { amount, timing); irrigation (amount, timing); crop } \\
\text { rotation (crop types, rotation pattern). }\end{array}$ \\
\hline
\end{tabular}


submodel starts the simulation by assuming a soil with uniform temperature and water content profiles.

The model output includes daily moisture and temperature profiles, concentrations of residues, organic carbon, microbial biomass, soluble carbon, $\mathrm{NH}_{4}^{+}, \mathrm{NO}_{3}^{-}, \mathrm{NO}_{2}^{-}, \mathrm{N}_{2} \mathrm{O}$, and $\mathrm{N}_{2}$ in the profile, and emissions of $\mathrm{N}_{2} \mathrm{O}, \mathrm{N}_{2}, \mathrm{NH}_{3}$, and $\mathrm{CO}_{2}$ from the soil.

\section{SENSITTVITY ANALYSIS}

To test the response of the sub-models and the complete model to variations of relevant parameters from baseline conditions, four sensitivity analyses were conducted: (1) the sensitivity of soil moisture to soil texture and rainfall patterns; (2) the sensitivity of decomposition to drying period duration, soil temperature, soil moisture, initial residue, and organic C; (3) the sensitivity of denitrification to soil-soluble $C$, nitrate, and rainfall duration; and (4) the sensitivity of total model behavior for an annual simulation to variations in soil properties, initial organic $\mathbf{C}$, annual precipitation, and temperature.

In order to unravel the complex behavior of DNDC our sensitivity analyses were conducted by varying one parameter and fixing others during one cycle. This sensitivity analysis does not validate the model but demonstrates that the model behavior is consistent with its structure and assumptions, as described in section 2. Model validations against field measurements are reported in a companion paper [ $\mathrm{Li}$ et al., this issue].

\subsection{Soil Moisture and Rainfall Patterns: The Thermal-Hydraulic Submodel}

The DNDC model illustrates the importance of soil moisture to both denitrification and decomposition. This section examines two tests of the sensitivity of the thermalhydraulic submodel to soil texture and imposed precipitation/irrigation conditions, one to rainfall intervals and the other to rainfall amounts.

In the first test the thermal-hydraulic submodel was run for five different rainfall patterns spread over a 90-day period: (1) $1.25 \mathrm{~cm}$ of rain in 5 hours every 4 days, (2) $2.50 \mathrm{~cm}$ of rain in 5 hours every 8 days, (3) $3.75 \mathrm{~cm}$ of rain in 5 hours every 12 days, (4) $5.00 \mathrm{~cm}$ of rain in 5 hours every 16 days, and (5) $6.25 \mathrm{~cm}$ of rain in 5 hours every 20 days. The total rainfall was the same for each simulation. For each soil type the amount of time the soil was dry (water content $<40 \%$ water-filled pore space) and the amount of time the soil was wet (water content $>65 \%$ water-filled pore space) increased as the rainfall interval increased, while the time that the soil was at an intermediate water content decreased (Figure 6). Other things being equal, we would expect $\mathrm{N}_{2} \mathrm{O}$ emissions to increase as both rainfall interval and duration increased.

Two simulation studies examined the effects of increased rain amounts for evenly spaced storms (10-day intervals): one varied rainfall intensity and the other varied rainfall duration. Both had the expected effect of increasing the amount of time the soils were quite wet ( $>65 \%$ pore space occupied) and decreasing the amount of time the soils were dry. For all thermal-hydraulic submodel tests, sandier soils were drier than the clayey or organic soils in any particular simulation.
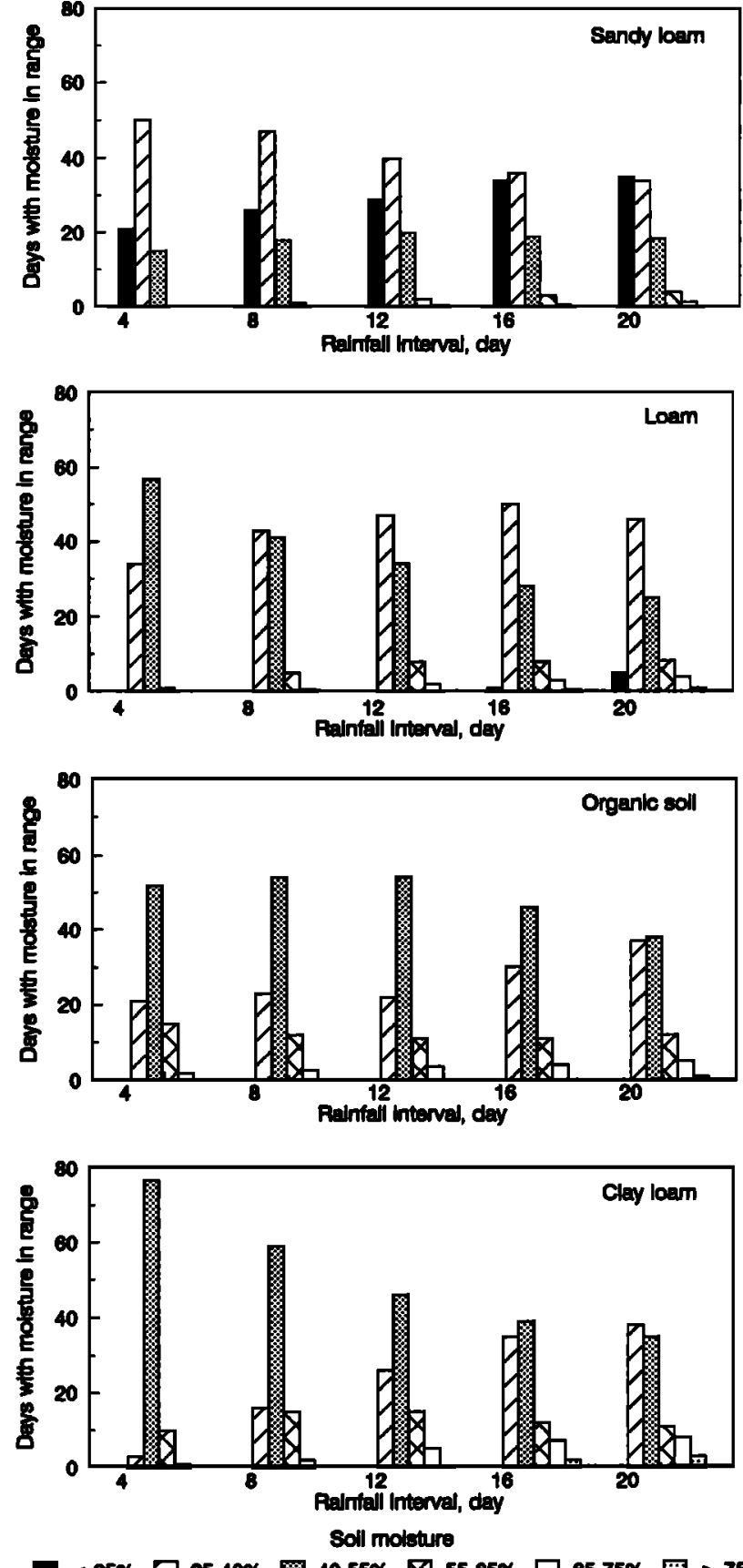

$<25 \% \square$ 25-40\% 40-55\% Х 55-65\% $\square$ 85-75\% 圂 > 75\%

Fig. 6. Soil moisture and rainfall patterns. Soil moisture dependence on rain storm interval (days between storms) for sandy loam, loam, clay loam, and organic soils. The height of the bars represent the amount of time, in days, that the top $20 \mathrm{~cm}$ of the soil had an average water-filled pore space in the range indicated.

\subsection{Soluble Carbon and Nitrate Availability in Soil: The Decomposition Submodel}

Both soluble $\mathrm{C}$ and $\mathrm{NO}_{3}^{-}$are the products of decomposition and other oxidation reactions in soils. In DNDC the levels of the two substrates reflect the interactions of several factors, including initial organic residues, total organic carbon, soil moisture and temperature, and decomposition duration. In this section we examine the sensitivity of the decomposition submodel, which generates soluble carbon and 
TABLE 9. Standard Conditions for Sensitivity Analysis of Decomposition and Denitrification Submodels

\begin{tabular}{lll}
\hline \multicolumn{1}{c}{ Item } & $\begin{array}{l}\text { Decomposition } \\
\text { Submodel }\end{array}$ & $\begin{array}{l}\text { Denitrification } \\
\text { Submodel }\end{array}$ \\
\hline Soil type & loam & $10 a \mathrm{~m}$ \\
Soil density & $1.5 \mathrm{~g} / \mathrm{cm}^{3}$ & $1.5 \mathrm{~g} / \mathrm{cm}^{3}$ \\
Soil $\mathrm{pH}$ & 7.0 & 7.0 \\
Soil temperature & $20^{\circ} \mathrm{C}$ & $20^{\circ} \mathrm{C}$ \\
Initial residue & $10 \mathrm{~g} \mathrm{C/kg} \mathrm{soil}$ & \\
Initial organic C & $10 \mathrm{~g} \mathrm{C/kg} \mathrm{soil}$ & $10 \mathrm{~g} \mathrm{C} / \mathrm{kg} \mathrm{soil}$ \\
Initial soluble C & & $20 \mathrm{mg} \mathrm{C} / \mathrm{kg} \mathrm{soil}$ \\
Initial nitrate & $100 \mathrm{mg} \mathrm{N} / \mathrm{kg} \mathrm{soil}$ & $100 \mathrm{mg} \mathrm{N} / \mathrm{kg} \mathrm{soil}$ \\
Initial ammonium & $5 \mathrm{mg} \mathrm{N} / \mathrm{kg} \mathrm{soil}$ & \\
Dry period duration & $30 \mathrm{days}$ & \\
Rainfall intensity & & $0.5 \mathrm{~cm} / \mathrm{h}$ \\
Rainfall duration & & $5 \mathrm{hours}$ \\
Nitrate in rainwater & & $1 \mathrm{mg} \mathrm{N} / 1$ \\
\end{tabular}

\footnotetext{
Decomposable residues, including plant residues and microbial polysaccharides,

'Active organic carbon, including microbial biomass and humads,

Water-soluble carbon.
}

nitrate pools, to variations in parameters from standard conditions (Table 9).

Effect of initial residue and organic carbon content. As the initial organic residue content increased from 0 to $0.1 \mathrm{~kg}$ $\mathrm{C} / \mathrm{kg}$ soil, final values (after a 30-day decomposition period) for both soluble $\mathrm{C}$ and $\mathrm{NO}_{3}{ }^{-}$increased (Figure 7). During the first two or three weeks of decomposition the very labile and labile residues rapidly decompose and produce relatively high levels of soil ammonium, which is nitrified to nitrate. The very labile residue pool has a low $C: N$ ratio and thus introduces a lot of nitrogen into the soil. The initial organic residue pool will affect results for the first two or three dry period-rainfall cycles, but the model then equilibrates to the imposed climate scenario and initial residue pools play a less important role.

As the initial organic carbon content increased from 0 to $0.1 \mathrm{~kg} \mathrm{C} / \mathrm{kg}$ soil, the production of soluble carbon also increased (Figure 8). Nitrate levels increased up to $0.05 \mathrm{~kg}$ $\mathrm{C} / \mathrm{kg}$ soil but then decreased slightly with further increases of organic carbon. This slight decrease in the $\mathrm{C}$-rich soil is related to the high population of microbial organisms (which

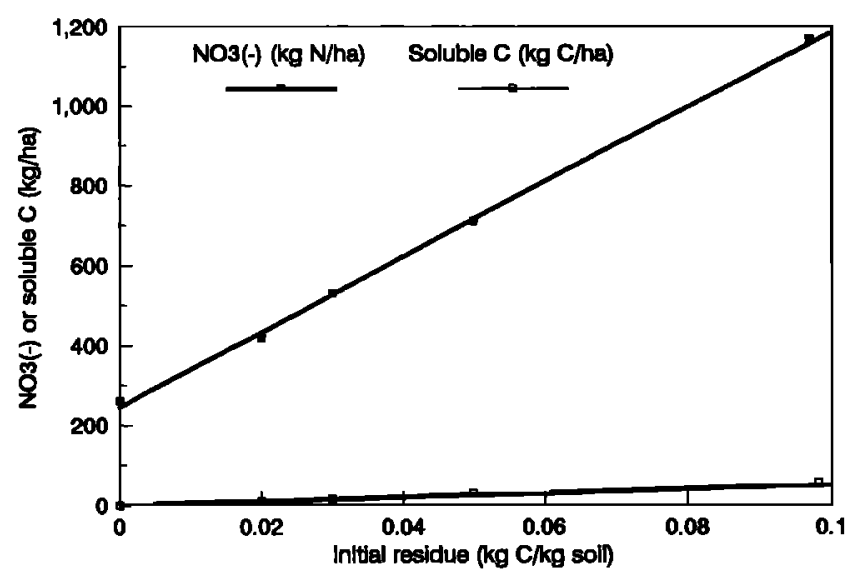

Fig. 7. Effect of initial residue content on nitrate and soluble $\mathbf{C}$ produced during the drying period. In the DNDC model, both soluble carbon and nitrate increase with an increase of initial residue content.

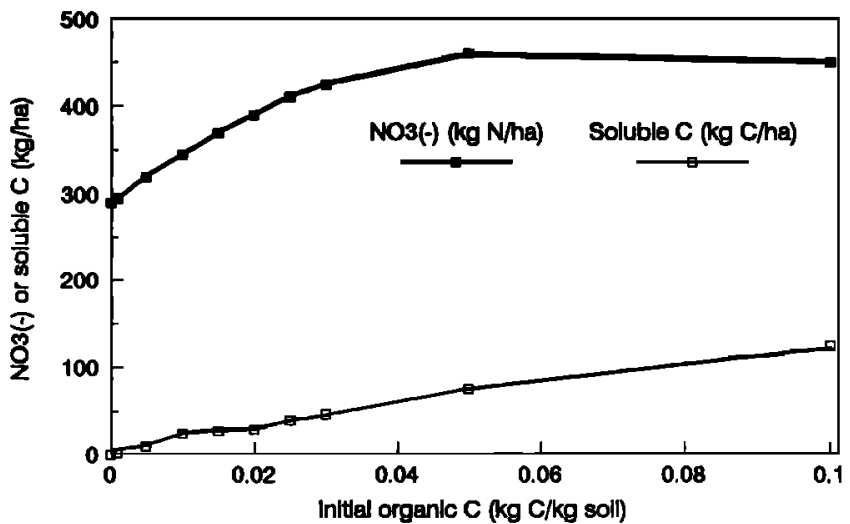

Fig. 8. Effect of initial soil active organic $\mathbf{C}$ on nitrate and soluble $\mathbf{C}$ produced during the drying period. In the DNDC model, when initial organic carbon increases, soluble carbon increases linearly, while $\mathrm{NO}_{3}$ increases at first and then decreases because of the competition between decomposition and assimilation.

follows from the higher initial organic carbon values); the microbes assimilate nitrate as it is produced by decomposition.

Effect of decomposition period duration. Under the standard conditions the soil nitrate content increased linearly as the decomposition period was extended, due to continuing nitrification of the ammonium released by decomposing organic matter. The soluble carbon level did not change since carbon decomposition and assimilation into microbial biomass reached a steady state (Figure 9).

Effect of soil climate. Soluble carbon and $\mathrm{NO}_{3}^{-}$reached maximum values when the water-occupied fraction was fixed at about $60 \%$ of the total porosity; both wetter and drier conditions limited the production of soluble carbon and $\mathrm{NO}_{3}^{-}$ (Figure 10). As the soil temperature increased from $0^{\circ}$ to $30^{\circ} \mathrm{C}$, soluble carbon and nitrate increased. Above $40^{\circ} \mathrm{C}$, soluble carbon gradually decreased and nitrate sharply decreased and then increased (Figure 11). At temperatures above $45^{\circ} \mathrm{C}$ (not normally found in field soils) the production of $\mathrm{CO}_{2}$ decreased because of the depression of microbial activity. Nitrification ceases above $45^{\circ} \mathrm{C}$, so no nitrate is produced, but the reduction in nitrogen assimilation due to

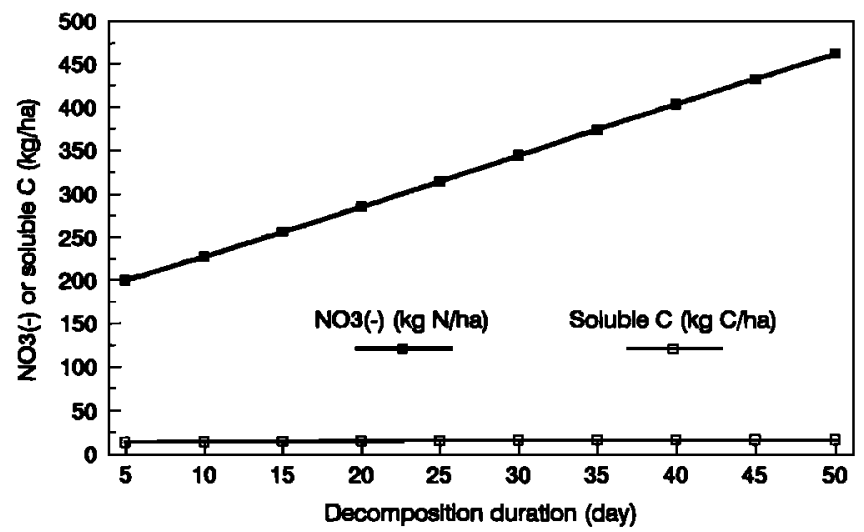

Fig. 9. Effect of decomposition duration on nitrate and soluble $\mathbf{C}$ produced during the drying period. In the DNDC model, nitrate increases with an increase in decomposition duration. Soluble carbon, an intermediate product during decomposition, does not change. 


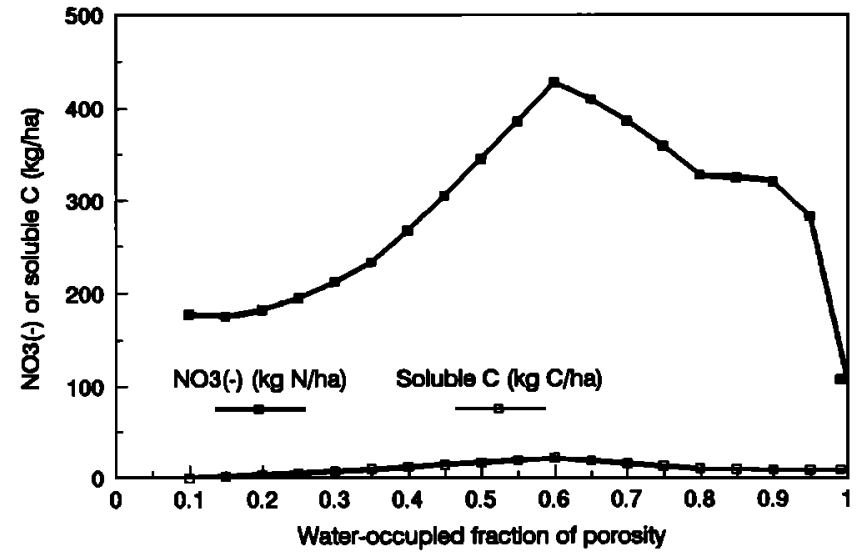

Fig. 10. Effect of soil moisture on nitrate and soluble $\mathrm{C}$ produced during the drying period. A soil moisture content of $60 \%$ water filled pore space is optimal for producing soluble carbon and nitrate during decomposition and nitrification process in the DNDC model.

suppressed microbial activity means that more of the initial nitrate pool remains after the 30-day decomposition period.

Effect of initial ammonium concentration on $\mathrm{N}_{2} \mathrm{O}$ emissions. $\mathrm{N}_{2} \mathrm{O}$ emissions from nitrification are modeled as a function of soil water ammonium concentration, soil temperature, and soil moisture. The response of the model to changes in the initial ammonium concentrations is large initially but temporary (Figure 12). Within 1 week all cases converged on a stable low level of $0.5 \mathrm{~g} \mathrm{~N} \mathrm{ha} \mathrm{d}^{-1} \mathrm{~d}^{-1}$. This value is a function of soil temperature, moisture, and the rate of $\mathrm{NH}_{4}{ }^{+}$ production through decomposition processes.

\subsection{Emissions of $\mathrm{N}_{2} \mathrm{O}$ During A Rainfall Event: The Denitrification Submodel}

During normal model operation the denitrification submodel receives substrate status information from the decomposition submodel at the beginning of each rain event. For this sensitivity study, the denitrification model was run alone using standard conditions (Table 9).

Effect of soluble carbon and nitrate contents. Soluble $\mathrm{C}$

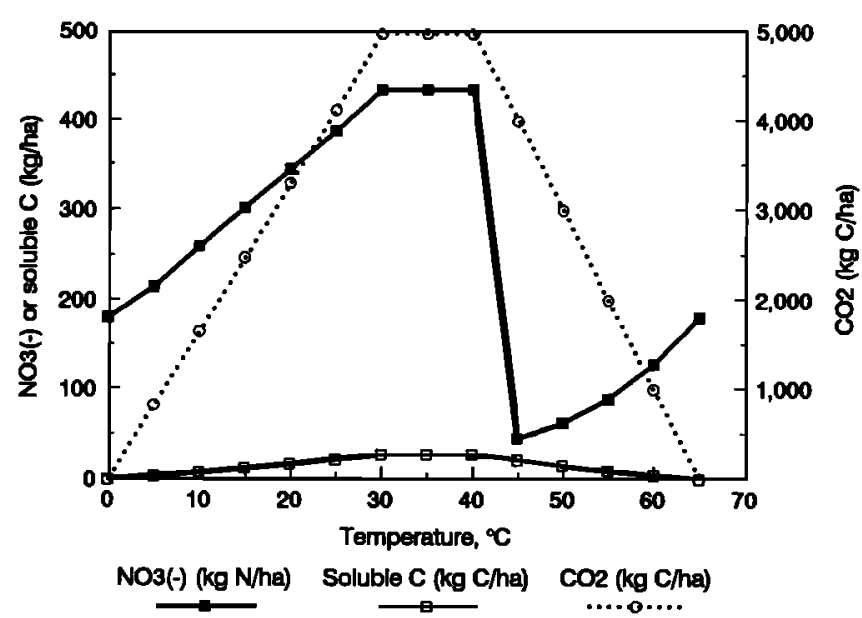

Fig. 11. Effect of soil temperahure on nitrate and soluble $\mathbf{C}$ produced during the drying period. A soil temperature of $30^{\circ}-40^{\circ} \mathrm{C}$ is optimal for decomposition and nitrification processes in the DNDC model.

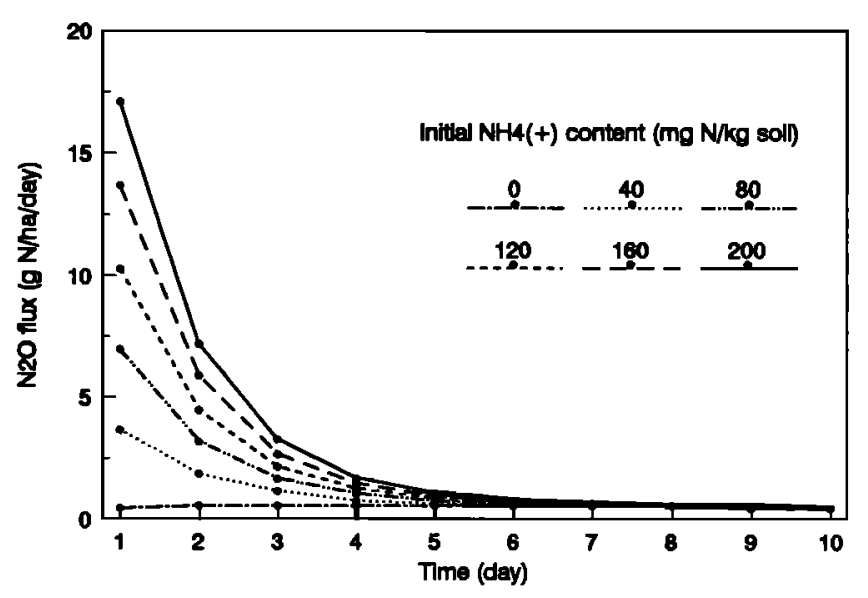

Fig. 12. Effect of initial ammonium content on $\mathrm{N}_{2} \mathrm{O}$ flux. Initial ammonium concentration only influences the short-term evolution of $\mathrm{N}_{2} \mathrm{O}$ in nitrification in the DNDC model. Evolved $\mathrm{N}_{2} \mathrm{O}$ rapidly decreases over 7 days to a stable low level because $\mathrm{NH}_{4}{ }^{+}$is transformed into $\mathrm{NO}_{3}^{-}$.

and $\mathrm{NO}_{3}^{-}$are the main substrates necessary to keep denitrifiers active under anaerobic conditions. As the initial value of soluble carbon increased, the rise in total denitrification $\left(\mathrm{N}_{2} \mathrm{O}+\mathrm{N}_{2}\right)$ depended on the initial content of $\mathrm{NO}_{3}{ }^{-}$in soils (Figure 13). For $\mathrm{NO}_{3}^{-}$levels below about 30 $\mathrm{mg} \mathrm{N} / \mathrm{kg}$ soil and soluble carbon greater than $10 \mathrm{mg} \mathrm{C} / \mathrm{kg}$ soil, nitrate limited total denitrification. Increasing soluble $\mathrm{C}$ can decrease $\mathrm{N}_{2} \mathrm{O}$ emission because it lowers the ratio of $\mathrm{N}_{2} \mathrm{O} / \mathrm{N}_{2}$ produced by supplying sufficient carbon substrate to complete the denitrification process (Figures 14 and 15). If the content of soluble carbon is fixed, increasing the initial $\mathrm{NO}_{3}{ }^{-}$content will not necessarily increase $\mathrm{N}_{2} \mathrm{O}$ emissions (Figure 15). Thus the relationship between $\mathrm{N}_{2} \mathrm{O}$ emission and the soluble carbon and $\mathrm{NO}_{3}{ }^{-}$contents in the soil appears to be quite complex. These results are consistent with numerous observations which indicate (1) water-soluble carbon is highly correlated with denitrification activity and (2) increasing carbon availability generally decreases the ratio of $\mathrm{N}_{2} \mathrm{O} / \mathrm{N}_{2}$ [Burford and Bremner, 1975; Smith and Tiedje, 1979; Focht and Verstraete, 1977; Nommik, 1956; and Delwiche, 1959]. These relationships between soluble carbon and nitrate could be important for reducing $\mathrm{N}_{2} \mathrm{O}$ emission

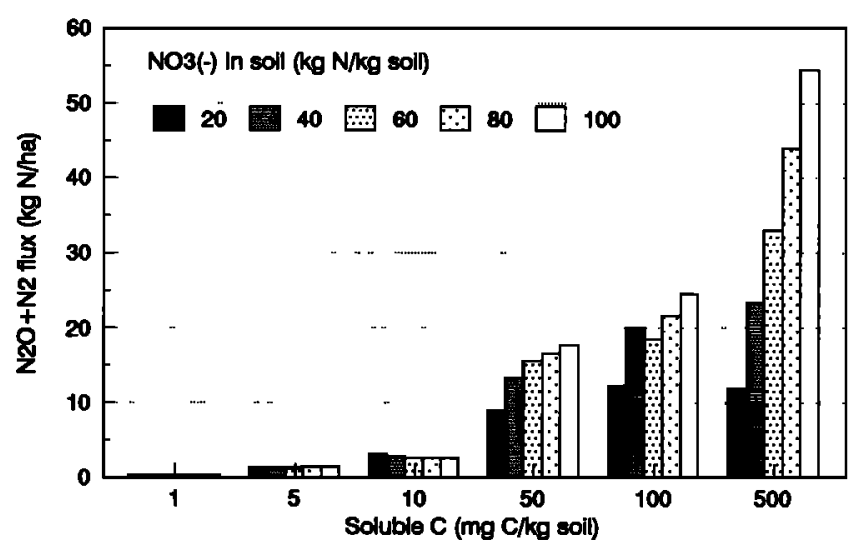

Fig. 13. Effect of soluble $C$ and nitrate on denitrification rate. Increases in soluble carbon (1-500 mg C/kg soil) and/or nitrate (20-100 mg N/kg soil) generally cause total denitrification to increase. Either carbon or nitrate can be a limiting factor for denitrification. 


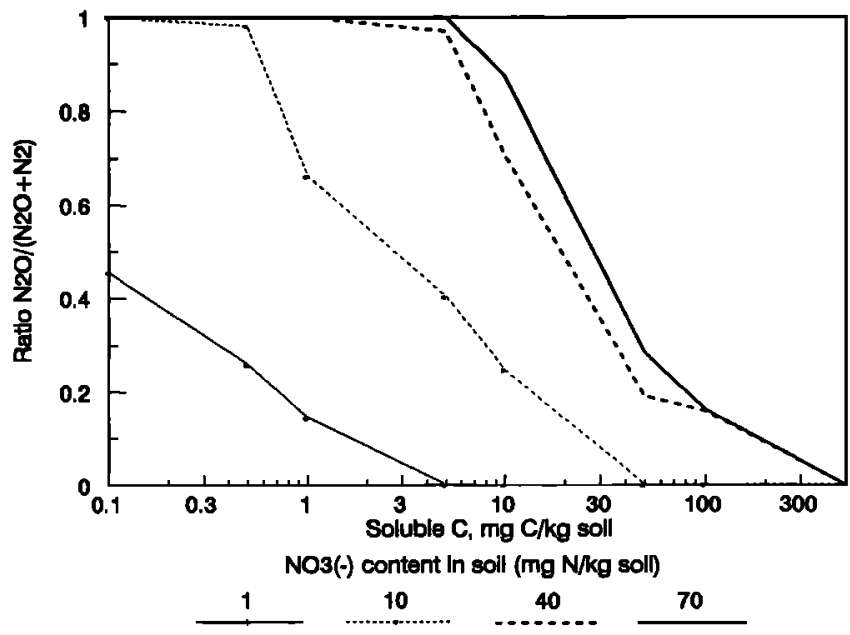

Fig. 14. Effect of soluble $C$ and nitrate on the $\mathrm{N}_{2} \mathrm{O} /\left(\mathrm{N}_{2} \mathrm{O}+\mathrm{N}_{2}\right)$ ratio. In the DNDC model, soluble carbon often limits the extent of denitrification. With increased soluble carbon, $\mathbf{N}_{2}$ production increases and the $\mathrm{N}_{2} \mathrm{O} /\left(\mathrm{N}_{2} \mathrm{O}+\mathrm{N}_{2}\right)$ ratio decreases.

from soils through changing the manner of fertilizer applications.

It is important to point out that initial values of soluble carbon and nitrate will not actually affect the model behavior significantly over a series of rain events (see Section 4.4). The denitrification submodel receives the levels of soluble carbon and nitrate as input from the decomposition submodel, and so these become internal variables after a couple of rain events. The sensitivity study, however, does demonstrate the interaction between these two pools.

Effect of rainfall duration. As rainfall duration increased from 1 to 10 hours, $\mathrm{N}_{2} \mathrm{O}$ and $\mathrm{N}_{2} \mathrm{O}+\mathrm{N}_{2}$ emissions increased in a near linear fashion (Figure 16). This was due to the increased volume and duration of anaerobic (denitrifying) conditions in the soil. Under field conditions this continuous increase in denitrification emissions with rainfall duration may not always occur. In this simulation, initial levels of soluble carbon and nitrate were relatively high insuring ample denitrification substrates when the rainfall occurred.

\subsection{Annual $\mathrm{N}_{2} \mathrm{O}$ Emissions: The DNDC Model}

The complete DNDC model was tested for its sensitivity to various climate and soil parameters over a 1-year simulation. A set of standard climate/soil conditions was developed, based on the climate and soils of Iowa [United States Department of Agriculture (USDA) 1989, 1967]. In order to determine the effects of different climate or soil properties on annual emissions of $\mathrm{N}_{2} \mathrm{O}$, annual simulations were conducted by varying each parameter by $\pm 20 \%$ while holding the others fixed (Table 10). The results of this analysis show that the sensitivities of total denitrification $\left(\mathrm{N}_{2} \mathrm{O}+\mathrm{N}_{2}\right), \mathrm{N}_{2} \mathrm{O}$ emissions, and $\mathrm{CO}_{2}$ emissions to the climate/soil parameters are quite different (Figure 17). None of these sensitivity studies test the model sensitivity to different agricultural practices.

Annual total denitrification. Variations in annual precipitation had the greatest effect on the annual total denitrification (see Figure 17a); when annual precipitation was increased by $20 \%$, total denitrification increased by more than $50 \%$. Higher precipitation keeps the surface soil under anaerobic conditions for a longer time, enhancing denitrification. Soil $p \mathrm{H}$ had the second largest effect. When soil $p H$ was reduced from 6.0 to 4.8 , the annual denitrification rate decreased by $40 \%$; denitrifiers are very sensitive to a low $\mathrm{pH}$ environment. When the mean annual temperature or initial total organic $C$ were increased by $20 \%$, total denitrification also increased by about $20 \%$. Higher temperatures stimulate denitrifier and decomposition activity; higher organic $\mathbf{C}$ provides more substrates (soluble $\mathbf{C}$ and nitrate) to support the growth of denitrifiers. Changes in soil density, clay content, rainfall nitrate, initial soil nitrate, and initial soil ammonium had slight to no effect on total denitrification. Rainfall nitrate at these levels $(0.8-1.2 \mathrm{mg}$ $\mathrm{N} / \mathrm{L}$ ) is a small nitrate source $(6 \mathrm{~kg} \mathrm{~N} / \mathrm{ha} / \mathrm{yr}$ ) relative to modeled nitrification at this site $(286 \mathrm{~kg} \mathrm{~N} / \mathrm{ha} / \mathrm{yr})$.

Annual $\mathrm{N}_{2} \mathrm{O}$ emission. Because the ratio of $\mathrm{N}_{2} \mathrm{O}$ production to total denitrification $\left(\mathrm{N}_{2} \mathrm{O}+\mathrm{N}_{2}\right)$ depends on many factors, the behavior of the annual $\mathrm{N}_{2} \mathrm{O}$ emissions is different from that of total denitrification (Figure 17b). Soil texture (clay content) and density had the greatest effect on $\mathrm{N}_{2} \mathrm{O}$ emissions. When soil clay content was decreased by $20 \%$, the annual

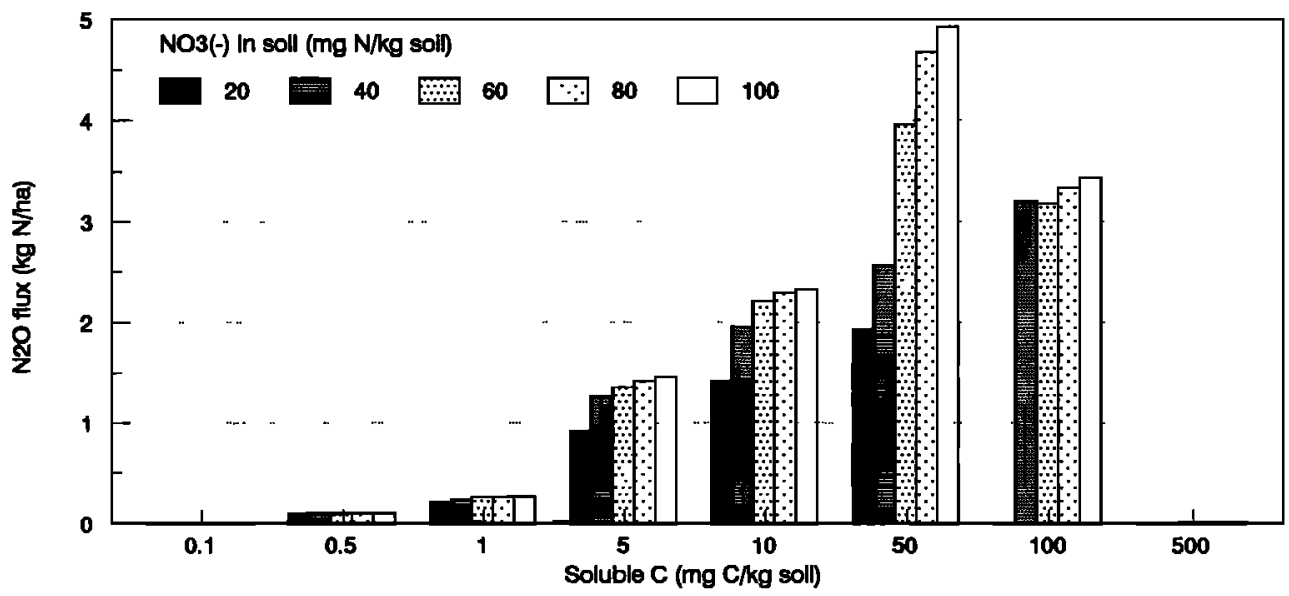

Fig. 15. Bffect of soluble $\mathrm{C}$ and nitrate on $\mathrm{N}_{2} \mathrm{O}$ emission. Changes in the modeled $\mathrm{N}_{2} \mathrm{O}$ emission rates due to increasing soil nitrate content depend on the level of soluble carbon in the soil. 


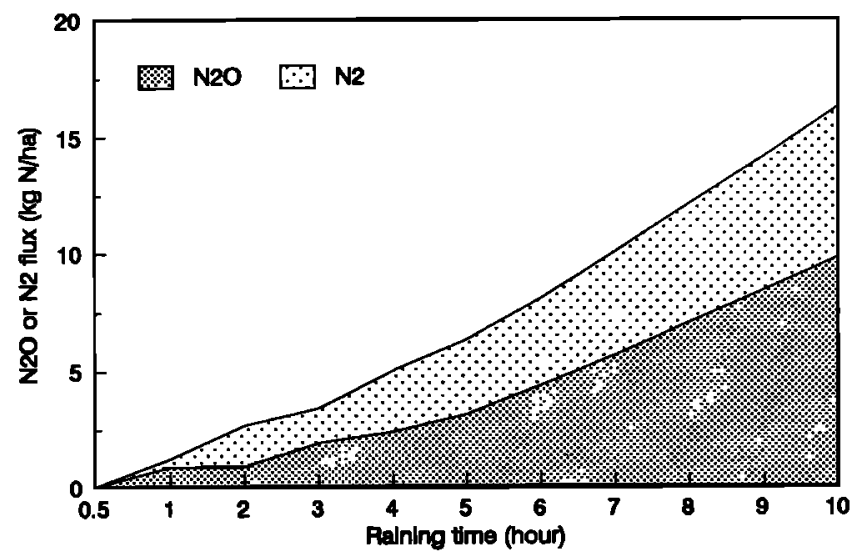

Fig. 16. Effect of rainfall duration on $\mathrm{N}_{2} \mathrm{O}$ and $\mathrm{N}_{2}$ flux. Modeled $\mathrm{N}_{2} \mathrm{O}$ and $\mathrm{N}_{2}$ emissions increase linearly with an increase in rainfall duration when carbon and nitrate substrates do not limit denitrification.

$\mathrm{N}_{2} \mathrm{O}$ emissions increased by more than $40 \%$. This phenomenon is due to the stronger adsorption by clays of $\mathrm{N}_{2} \mathrm{O}$ than of $\mathrm{N}_{2}$; the model clay content was changed without changing the soil hydraulic properties, so soil moisture changes had no effect here. Since we defined soil organic C as $\mathrm{kg} \mathrm{C}$ per $\mathrm{kg}$ soil, an increase in soil density automatically causes an increase in organic C. An increase in organic $\mathbf{C}$ will increase the microbial biomass which tends to increase $\mathrm{N}_{2} \mathrm{O}$ production more than $\mathrm{N}_{2}$ production because of the time constraints set by various wet periods. Thus the $\mathrm{N}_{2} \mathrm{O} /\left(\mathrm{N}_{2} \mathrm{O}+\mathrm{N}_{2}\right)$ ratio generally rises.

In the same vein an increase in annual precipitation greatly increased annual $\mathrm{N}_{2}$ emission but slightly reduced $\mathrm{N}_{2} \mathrm{O}$ emission (Figure 17); anaerobic conditions last longer, allowing denitrification processes to continue more toward completion $\left(\mathrm{N}_{2}\right.$ rather than $\left.\mathrm{N}_{2} \mathrm{O}\right)$. When soil temperature was increased by $20 \%$, the annual $\mathrm{N}_{2} \mathrm{O}$ emissions increased by $14 \%$ because of enhanced microbial activity. Annual $\mathrm{N}_{2} \mathrm{O}$ emissions decreased slightly with either an increase or a decrease in soil $p \mathrm{H}$ reflecting the optimal $p \mathrm{H}$ range for $\mathrm{N}_{2} \mathrm{O}$ production. Nitrate concentration in rainfall, initial soil nitrate, and initial ammonium had little to no effect on annual $\mathrm{N}_{2} \mathrm{O}$ emissions.

Annual $\mathrm{CO}_{2}$ emission. Total organic $\mathrm{C}$ strongly influenced annual $\mathrm{CO}_{2}$ emissions (Figure 17c) because the soil microbial

TABLE 10. Standard Conditions and Variations for Sensitivity Analysis on DNDC Model

\begin{tabular}{|c|c|c|c|}
\hline \multirow[b]{2}{*}{ Item } & \multicolumn{3}{|c|}{ Condition } \\
\hline & Standard & Variation & Unit \\
\hline $\begin{array}{l}\text { Annual rainfall eventse } \\
\text { Annual precipitation } \\
\text { Annual average temperature } \\
\text { Nitrate content in rain } \\
\text { Soil clay content } \\
\text { Soil density } \\
\text { Soil pH } \\
\text { Initial total organic C' } \\
\text { Initial soil nitrate } \\
\text { Initial soil ammonium }\end{array}$ & $\begin{array}{l}24 \\
82.5 \\
9.1 \\
1.0 \\
34 \% \\
1.4 \\
6.0 \\
0.03 \\
10 \\
10\end{array}$ & $\begin{array}{l}29-21 \\
99.1-66.0 \\
10.9-7.3 \\
1.2-0.8 \\
40 \%-27 \% \\
1.68-1.12 \\
7.2-4.8 \\
0.036-0.024 \\
12-8 \\
12-8\end{array}$ & 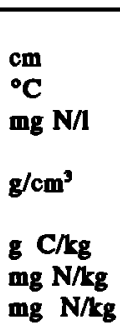 \\
\hline
\end{tabular}

\footnotetext{
Teavy and intermediate rainfalls,

'Including plant residues, microbial polysaccharide, and other organic matter.
}

pool size varies directly with total organic carbon. The same effect occurs with a change in soil density $\left(\mathrm{g} \mathrm{soil} / \mathrm{cm}^{3}\right)$. Soil clay content showed a large inverse effect on annual $\mathrm{CO}_{2}$ emission; clays can adsorb organic $\mathrm{C}$ and shield it from decomposition. When soil temperature was increased (decreased) by $20 \%$, annual $\mathrm{CO}_{2}$ emissions increased (decreased) by $13 \%$, reflecting the general dependence of microbial activity on temperature. An increase in annual precipitation had a negative impact on annual $\mathrm{CO}_{2}$ emissions. Rates of decomposition are slowed with the increased frequency/duration of anaerobic conditions. Soil $p \mathrm{H}$, nitrate
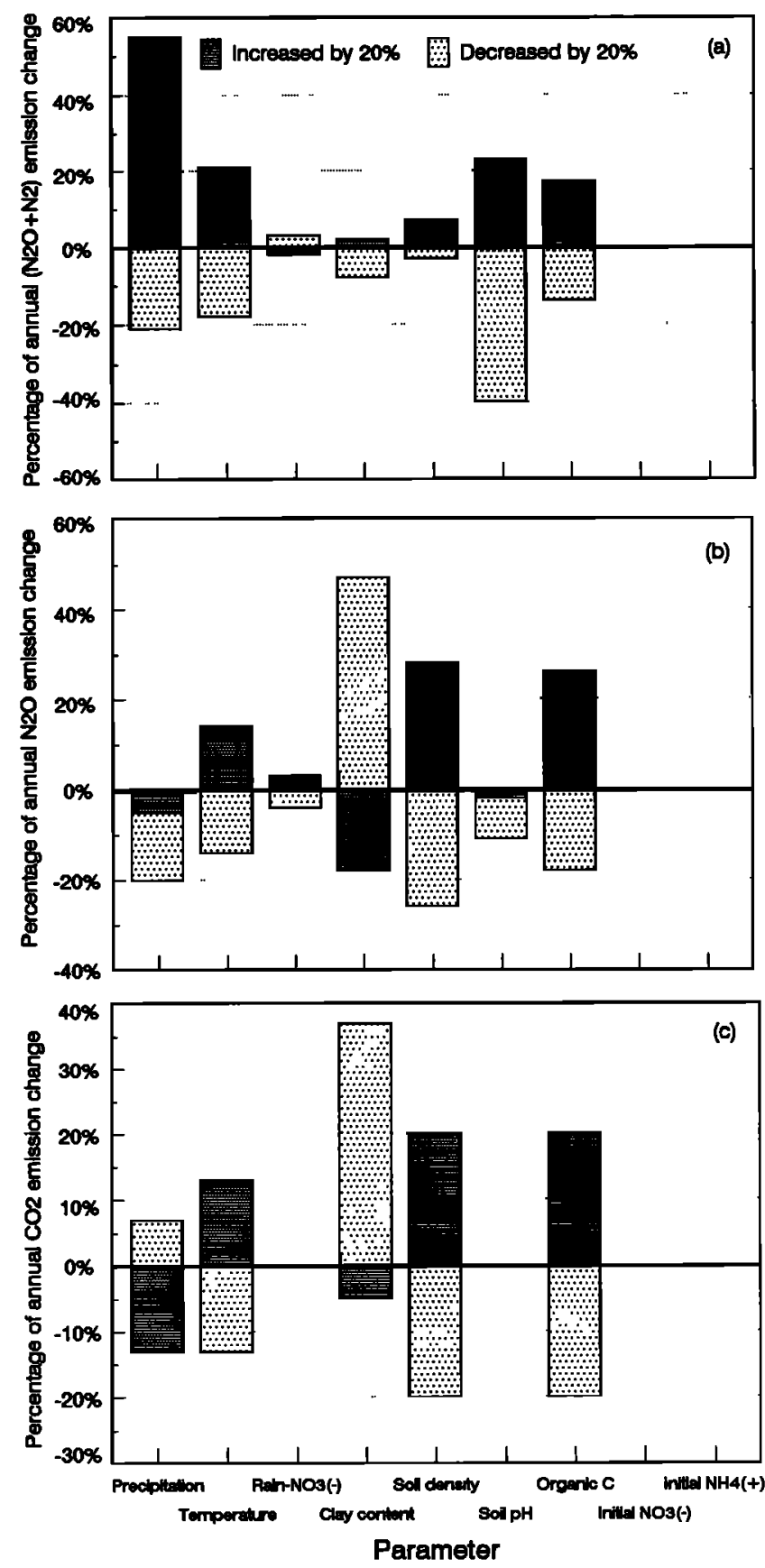

Fig. 17. Sensitivity of $\mathrm{N}_{2} \mathrm{O}+\mathrm{N}_{2}, \mathrm{~N}_{2} \mathrm{O}$ and $\mathrm{CO}_{2}$ emissions to increasing or decreasing input parameters by $20 \%$ in a loam soil in Iowa, USA. Changes in environmental parameter values ( $\pm 20 \%$ from standard conditions; see Table 4) cause variations in (a) annual total denitrification $\left(\mathrm{N}_{2} \mathrm{O}+\mathrm{N}_{2}\right)$ flux, (b) annual $\mathrm{N}_{2} \mathrm{O}$ flux, and (c) annual $\mathrm{CO}_{2}$ flux. 
content in rainfall, initial soil nitrate, and initial ammonium all had little or no effect on annual $\mathrm{CO}_{2}$ emissions.

\section{SUMMARY AND CONCLUSIONS}

This paper describes a process-oriented rain-event model of soil nitrogen and carbon biogeochemistry that has been developed to predict $\mathrm{N}_{2} \mathrm{O}$ emissions from agricultural soils over a growing season. A soil thermal-hydraulic model propagates a surface climate (daily mean air temperature and precipitation/irrigation) into the soil to determine soil temperature and moisture profiles. A decomposition submodel tracks the soluble carbon and nitrogen pools in the soil as plant residues decompose and soil microbes grow and die. A rain-event-initiated denitrification submodel calculates $\mathrm{N}_{2} \mathrm{O}$ and $\mathrm{N}_{2}$ production while the soil is wet during and following rain/irrigation events. The model allows for cropping, fertilizer and organic matter additions, and soil tillage so that agricultural practices can be simulated.

We performed a series of sensitivity studies of the total model and the three submodels to determine the factors which have strong effects on the behavior of DNDC and its three submodels (Table 11). Although the specific sensitivities depended on somewhat arbitrary standard conditions and variations, we feel that the model behavior (for $\mathrm{N}_{2} \mathrm{O}$ evolution, total denitrification, and $\mathrm{CO}_{2}$ emissions) is representative of what is (or would be) observed in the field. What these sensitivity studies do not portray are the impacts of agricultural land use practices and the interactions of the various processes as several factors change at once, as would happen when comparing different agroecosystems. Only through studying the complex interactions among soil climate, decomposition and denitrification processes, and agronomic practices can a complete picture of agroecosystem scale

TABLE 11. Highly Sensitive Factors Affecting DNDC Model and Submodels

\begin{tabular}{|c|c|c|}
\hline Model & Item & Highly Sensitive Factors \\
\hline DNDC model & $\mathbf{N}_{2} \mathbf{O}+\mathbf{N}_{2}$ & $\begin{array}{l}\text { (1) Soil clay content } \\
\text { (2) Soil organic C } \\
\text { (3) Mean annual temperature } \\
\text { (1) Annual precipitation } \\
\text { (2) Soil pH } \\
\text { (3) Mean annual temperature } \\
\text { (4) Soil organic C } \\
\text { (1) Soil organic C } \\
\text { (2) Soil clay content } \\
\text { (3) Mean annual temperature } \\
\text { (4) Annual precipitation }\end{array}$ \\
\hline $\begin{array}{l}\text { Thermal- } \\
\text { hydraulic } \\
\text { submodel }\end{array}$ & $\begin{array}{l}\text { Soil } \\
\text { moisture }\end{array}$ & $\begin{array}{l}\text { (1) Rainfall patterns } \\
\text { (2) Soil texture }\end{array}$ \\
\hline $\begin{array}{l}\text { Decomposition } \\
\text { submodel }\end{array}$ & Soluble C & $\begin{array}{l}\text { (1) Initial organic C } \\
\text { (2) Soil temperature } \\
\text { (3) Soil moisture } \\
\text { (4) Dry period duration } \\
\text { (1) Initial organic C } \\
\text { (2) Dry duration } \\
\text { (3) Soil temperature } \\
\text { (4) Soil moisture }\end{array}$ \\
\hline $\begin{array}{l}\text { Denitrification } \\
\text { submodel }\end{array}$ & $\mathrm{N}_{2} \mathrm{O}$ & $\begin{array}{l}\text { (1) Precipitation } \\
\text { (2) Soil soluble C } \\
\text { (3) Soil nitrate } \\
\text { (4) Soil texture }\end{array}$ \\
\hline
\end{tabular}

nitrous oxide fluxes begin to emerge. A companion paper reports the comparison of DNDC simulations to field studies [Li et al., this issue].

Since most fundamental biogeochemical processes have been included in DNDC, it can potentially serve not only for estimating $\mathrm{N}_{2} \mathrm{O}$ emissions but also for other processes related to mass exchange between soil systems and the atmosphere, such as fertilizer efficiency, carbon balance in soils, $\mathrm{CH}_{4}$ and $\mathrm{CO}_{2}$ emissions, nitrogen leaching, and groundwater pollution.

\section{NOTATION}

\section{Thermal-Hydraulic Submodel Variables}

a ET parameter $\left(=0.49+0.079 \cdot\left[-7.71 e-5 \cdot \Gamma^{2}+6.75 e-7 \cdot 1^{3)}\right.\right.$.

$c_{\mathrm{x}}$ specific heat of material $\mathrm{x}, \mathrm{J} \mathrm{kg}^{-1}{ }^{\circ} \mathrm{C}^{-1}$.

DAY $_{1} 1 / 12$ of the day's hours of daylight.

$d \theta_{i}$ change in the water content of soil layer $i$.

d $t$ time step length, $\mathrm{s}$.

$d T_{i}$ change in temperature of soil layer.

$E$ actual $E T$, cm d-1.

$f$ drainage factor $(f$ is presently fixed at 1.0$)$.

$h_{\mathrm{i}}$ hydraulic head for level $i, \mathrm{~cm}$.

l ET parameter $\left\{=\Sigma_{\mathrm{n}-1}{ }^{12}\left(\mathrm{~T}_{\mathrm{a}}{ }^{*} / 5\right)^{1.5}\right\},{ }^{\circ} \mathrm{C}$.

$k_{\text {dyy }}$ mineral soil thermal conductivity $(0.029), \mathrm{J} \mathrm{cm} \mathrm{s}^{-1}{ }^{\circ} \mathrm{C}^{-1}$.

$k_{\mathrm{i}}$ total soil thermal conductivity of layer $i, \mathrm{~J} \mathrm{~cm} \mathrm{~s}{ }^{-1}{ }^{\circ} \mathrm{C}^{-1}$.

$k_{i,-1}$ average thermal conductivity of layers $i$ and $i-1, \mathrm{~J} \mathrm{~cm} \mathrm{~s}^{-1}{ }^{\circ} \mathrm{C}^{-1}$.

$k_{\text {oum }}$ organic matter thermal conductivity $(0.0025), \mathrm{J} \mathrm{cm} \mathrm{s}^{-1}{ }^{\circ} \mathrm{C}^{-1}$.

$k_{\text {man }}$ water thermal conductivity $(0.0057), \mathrm{J} \mathrm{cm} \mathrm{s}^{-1}{ }^{\circ} \mathrm{C}^{-1}$.

$\boldsymbol{K}_{\mathrm{i}, \mathrm{i}-1}$ average hydraulic conductivity of layers $\mathrm{i}$ and $\mathrm{i}-1, \mathrm{~cm} \mathrm{~s}^{-1}$.

$\boldsymbol{K}_{\mathbf{m}}$ saturated hydraulic conductivity, $\mathrm{cm} \mathrm{s}^{-1}$.

$l_{i}$ thickness of layer $i, \mathrm{~cm}$.

$m_{1}$ parameter $\left\{=y_{-}\left(1-W_{*}\right)^{2}-y_{*} \cdot \beta /\left[W_{*} \cdot\left(1-W_{*}\right)\right]\right\}, c m$.

$m_{2}$ parameter $\left\{=2 \cdot W_{-}-1-y_{*} \cdot \beta /\left(m_{1} \cdot W_{*}\right)\right\}$.

$n$ soil porosity.

$N M$ mumber of days in the month.

$q_{i,-1}$ heat flux from layer $i-1$ down to layer $i, \mathrm{~J} \mathrm{~s}^{1}$.

$Q_{i,-1}$ flow of water per unit area from layer $i-1$ down to layer $i, \mathrm{~cm} \mathrm{~s}^{1}$.

$t$ time, s.

$T_{\mathrm{i}}$ temperature for level $i,{ }^{\circ} \mathrm{C}$.

$T_{\text {max }}$ mean annual air temperature, ${ }^{\circ} \mathrm{C}$.

$T_{a}^{*}$ mean monthly air temperature of month $n,{ }^{\circ} \mathrm{C}$.

W. water content where retention curve has inflection (0.92).

$z_{\text {dowp }}$ depth where temperature variation assumed negligible $(500), \mathrm{cm}$.

$z_{i}$ depth of layer $i$ (positive down from surface), $\mathrm{cm}$.

$\beta$ soil water parameter (range $=4$ to 11.4 ).

$\sigma$ material density, $\mathrm{kg} \mathrm{m}^{-3}$.

$\theta_{i}$ layer $i$ water content (fraction pore volume occupied).

$\boldsymbol{\theta}_{k \text { se }}$ soil water content at field capacity.

$\theta_{\mathrm{vp}}$ soil water content at the plant wilting point.

$\phi_{\text {mat }}$ water tension parameter, $\mathrm{cm}$.

$\phi$. soil water tension at the inflection point, $\mathrm{cm}$.

Decomposition Submodel Variables

$A M$ accumulated $\mathrm{NH}_{3}$ loss at time $t, \mathrm{~mol} \mathrm{~cm}$.

$B$ total microbial biomass produced, $\mathrm{kg} \mathrm{C}$.

CLAY soil clay fractional content.

$\mathrm{CLAY}_{\text {a }}$ maximum clay fraction in model soils $(0.63)$.

$\mathrm{COP} \mathrm{CO}_{2}$ respired during residue decomposition, $\mathrm{kg} \mathrm{C}$.

$C P C$ produced by potential residue decomposition, $\mathrm{kg} \mathrm{C} \mathrm{ha}^{-1} \mathrm{~d}^{-1}$.

$D$ diffusion coefficient $(0.025), \mathrm{cm}^{2} \mathrm{~d}^{-1}$.

dNNO $\mathrm{NH}^{+}$converted to $\mathrm{NO}_{3}^{-}, \mathrm{kg} \mathrm{N} \mathrm{ha}^{-1} \mathrm{~d}^{-1}$.

eff microbial efficiency for decomposing residues.

FIXNH4 proportion of adsorbed $\mathrm{NH}_{4}{ }^{+}$.

$k_{1}$ specific decomposition rate (SDR) of labile fraction, $\alpha^{1}$.

$k_{\mathrm{r}}$ SDR of the resistant fraction, $\mathrm{d}^{-1 .}$

$\boldsymbol{K}_{\mathrm{NB}}$ dissociation constant for $\mathrm{NH}_{4}^{+}: \mathrm{NH}_{3}$ equilibrium.

$\boldsymbol{K}_{\mathrm{FDO}}$ dissociation constant for $\mathrm{H}^{+}: \mathrm{OH}^{-}$equilibrium. 
$K_{3 s}$ mitrification rate at $35^{\circ} \mathrm{C} \mathrm{(25),} \mathrm{mg} \mathrm{kg}^{-1}$ soil d

NH3 $\mathrm{NH}_{3}$ concentration in liquid phase, mol $\mathrm{cm}^{-3}$.

$\mathrm{NH}_{\mathbf{2}} \mathrm{NH}_{3}$ concentration in liquid phase, $\mathrm{mol} \mathrm{L}^{-1}$.

NH4 $\mathrm{NH}_{4}{ }^{+}$concentration in the soil liquid, $\mathrm{g} \mathrm{N} \mathrm{kg-1}$ soil.

$\mathrm{NH}_{\mathrm{m}} \mathrm{NH}_{4}^{+}$concentration in liquid phase, $\mathrm{mol} \mathrm{L}^{-1}$.

$N H 4(t)$ available $\mathrm{NH}_{4}{ }^{+}$at time $t, \mathrm{~kg} \mathrm{~N}^{-1}$.

$N P$ N produced by potential residue decomposition per day plus free $\mathrm{NH}_{4}{ }^{+}$and $\mathrm{NO}_{3}^{-}$in soil, $\mathrm{kg} \mathrm{N}$ ha ${ }^{-1}$.

$\mathrm{N} 2 \mathrm{O}$ daily emission of $\mathrm{N}_{2} \mathrm{O}$, $\mathrm{ng} \mathrm{N} \mathrm{g}^{-1}$ soil $\mathrm{d}^{-1}$.

$p H$ soil $p \mathrm{H}$.

$R_{\mathrm{c}}$ total decomposed residue $\mathrm{C}, \mathrm{kg} \mathrm{C}$.

$S$ labile fraction of organic $C$ compounds in the pool.

$t$ time, d.

$\mu_{\text {mim }}$ combined temperature and moisture reduction factor.

$\mu_{\text {CLAY }}$ clay content reduction factor $\{=\log (.14 / C L A Y)+1\}$.

$\mu_{\mathrm{CN}} \mathrm{C}: \mathrm{N}$ ratio reduction factor $\{=0.2+7.2 /(\mathrm{CP} / \mathrm{NP})\}$.

$\mu_{m, 1}$ moisture reduction factor for nitrification.

$\mu_{h, \text { }}$ temperature reduction factor for nitrification.

Denitrification Submodel Variables

$A D$ adsorption factor depending on clay content in the soil \{range $=0-2$ \}.

$A M$ accumulated $\mathrm{NH}_{3}$ loss at time $t, \mathrm{~mol} / \mathrm{cm}^{2}$.

$B$ total biomass of the denitrifier, $\mathrm{kg} \mathrm{C} \mathrm{ha-3}$.

$(d B / d t)_{2}$ potential growth rate of denitrifier biomass, $\mathrm{kg} \mathrm{C} \mathrm{ha-1}^{-1}$.

$(d B / d t)_{d}$ death rate of denitrifier biomass, $\mathrm{kg} \mathrm{C} \mathrm{ha}^{-1} \mathrm{~h}^{-1}$.

$C$ mineralized carbon concentration in the soil, $\mathrm{kg} \mathrm{C} \mathrm{ha}^{-1}$.

$C_{\infty}$ consumed soluble $\mathrm{C}, \mathrm{kg} \mathrm{C} \mathrm{ha}{ }^{-1}$.

$C_{\text {cout }}$ total consumption of soluble $\mathrm{C}, \mathrm{kg} \mathrm{C}^{\mathrm{Ca}} \mathrm{ga}^{-1}$.

$C N R_{\mathrm{DN}} \mathrm{C} / \mathrm{N}$ ratio in denitrifiers (3.45).

$\mathrm{CO} 2 \mathrm{CO}_{2}$ production, $\mathrm{kg} \mathrm{C} \mathrm{ha-1}$.

$K_{\varepsilon, 1 / 2}$ half-saturation value of soluble $\mathrm{C}, \mathrm{kg} \mathrm{C} \mathrm{m}^{-3}$.

$K_{\mathrm{NzO}, 1 / 2}$ half-saturation value of $\mathrm{NO}_{3}^{-}, \mathrm{NO}_{2}^{-}$, or $\mathrm{N}_{2} \mathrm{O}, \mathrm{kg} \mathrm{N} \mathrm{m}^{-3}$.

$M_{\mathrm{c}}$ maintenance coefficient of carbon, $\mathrm{kg} \mathrm{C} \mathrm{kg}^{-1} \mathrm{C} \mathrm{h}^{-1}$.

$M_{\mathrm{N} 2 \mathrm{O}}$ maintenance coefficient of $\mathrm{NO}_{3}^{-}, \mathrm{NO}_{2}^{-}$, or $\mathrm{N}_{2} \mathrm{O}, \mathrm{kg} \mathrm{N} \mathrm{kg} \mathrm{h}^{-1}$.

$N$ total nitrogen as $\mathrm{NO}_{3}{ }^{-}, \mathrm{NO}_{2}{ }^{-}$, and $\mathrm{N}_{2} \mathrm{O}, \mathrm{kg} \mathrm{N} \mathrm{ha}^{-1}$.

$(d N / d t)_{\text {ming }}$ mitrogen assimilation rate by denitrifiers, $\mathrm{kg} \mathrm{N} \mathrm{ha}^{-1} \mathrm{~d}^{-1}$.

$\mathrm{NuOy}$ concentration of $\mathrm{NO}_{3}^{-}, \mathrm{NO}_{2}{ }^{-}$, or $\mathrm{N}_{2} \mathrm{O}$ in soil water, $\mathrm{kg} \mathrm{N} \mathrm{ha}^{-1}$.

$P(N 2 O)$ imitted fraction of the total $\mathrm{N}_{2} \mathrm{O}$ evolved in a day.

$P(N 2)$ emitted fraction of the total $\mathrm{N}_{2}$ evolved in a day.

$P A$ air-filled fraction of the total porosity.

$P H$ soil $p H$.

$t$ time, d.

$T$ temperature, ${ }^{\circ} \mathrm{C}$

$u_{\mathrm{DN}}$ relative growth rate of the denitrifiers.

$u_{\mathrm{NzO}}$ relative growth rate of $\mathrm{NO}_{3}^{-}, \mathrm{NO}_{2}^{-}$, or $\mathrm{N}_{2} \mathrm{O}$ denitrifiers.

$u_{\mathrm{NzO}}$, maximum growth rate of $\mathrm{NO}_{3} ; \mathrm{NO}_{2}^{-}$, or $\mathrm{N}_{2} \mathrm{O}$ denitrifiers.

$Y_{c}$ maximum growth yield on soluble carbon, $\mathrm{kg} \mathrm{C} \mathrm{kg}^{-1} \mathrm{C}$.

$Y_{\mathrm{N} z}$ y maximum growth yield on $\mathrm{NO}_{3}^{-}, \mathrm{NO}_{2}^{-}$, or $\mathrm{N}_{2} \mathrm{O}, \mathrm{kg} \mathrm{C} \mathrm{kg}^{-1} \mathrm{~N}$.

$\mu_{\text {ptiNs }}$ sy soil $p H$ reduction factor.

$\boldsymbol{t}_{\text {L, }}$ soil temperature reduction factor.

Acknowledgments. We wish to thank R. Harriss, J. Aber, W. Bowden, and $R$. Boone for many valuable comments and discussions; and thanks also to R. Terry and P. Matson for helpful comments on an earlier draft. Acknowledgment is made to Climate Change Division, Office of Policy, Planning and Evaluation, United States Environmental Protection Agency, which supported this study under grant 68-W8-0113. This work was also supported by a NASA Graduate Student Researchers Program Fellowship to Steve Frolking.

\section{REFERENCE}

Alexander, M., Microbial Ecology, John Wiley, New York, 1971.

Anderson, T. H., and K. H. Domsch, Ratios of microbial biomass carbon to total organic carbon in arable soils, Soil Biol. Biochem., 21, 471-479, 1989.

Bader, F. G., Analysis of double-substrate limited growth, Biotechnol. Bioeng., 20, 183-202, 1978.
Bailey, L. D., and E. G. Beauchamp, Effects of temperature on $\mathrm{NO}_{3}{ }^{-}$and $\mathrm{NO}_{2}^{-}$reduction, nitrogenous gas production, and redox potential in a saturated soil, Can. J. Soil Sci., 53, 213-218, 1973.

Batlach, R. M., and J. M. Tiedje, Kinetic explanation for accumulation of nitrite, nitric oxide, and nitrous oxide during bacterial denitrification, Appl. Environ. Microbiol., 42, 1074-1084, 1981.

Bouwman, A. F., Exchange of greenhouse gases between terrestrial ecosystems and the atmosphere, in Soils and the Greenhouse Effect, edited by A. F. Bouwman, John Wiley, New York, 1990.

Bras, R., Hydrology, An Introduction to Hydrologic Science, AddisonWesley, Reading, Mass., 1990.

Bremner, J. M., and A. M. Blackmer, Nitrous oxide: Emission from soils during nitrification of fertilizer nitrogen, Science, 199, 295-296, 1978.

Bremner, J. M., and A. M. Blackmer, Terrestrial nitrification as a source of atmospheric nitrous oxide, in Denitrification, Nitrification, and Atmospheric Nitrous Oxide, edited by C. C. Delwiche, John Wiley, New York, 1981.

Bremner, J. M., and K. Shaw, Denitrification in soil, I, Methods of investigation, J. Agric. Sci., 51, 22-39, 1958 .

Bremner, J. M., and X. Shaw, Denitrification in soil, II, Factors affecting denitrification, J. Agric. Sci., 51, 40-52, $1958 b$.

Burford, J. R., and J. M. Bremner, Relationships between the denitrification capacities of soils and total water-soluble and readily decomposable soil organic matter, Soll Biol. Biochem., 7, 389-394, 1975.

Chichester, F. W., J. O. Legg, and G. Stanford, Relative mineralization rates of indigenous and recently incorporated $15-\mathrm{N}$ labeled nitrogen, Soil Sci., 120, 455-460, 1975.

Cho, C. M., L. Sakdinan, and C. Chang, Denitrification intensity and capacity of three irrigated Alberth soils, Soil Sci. Soc. Am. J., 43, 949950, 1979.

Clapp, R. B., and G. M. Homberger, Empirical equations for some soil hydraulic properties, Water Resour. Res., 14, 601-604, 1978.

Clay, D. E., J. A. E. Molina, C. E. Clapp, and D. R. Linden, Nitrogentillage-residue management, II, Calibration of potential rate of nitrification by model simulation, Soil Sci. Soc. Am. J., 49, 322-325, 1985.

Crutzen, P. J., The influence of nitrogen oxides on the atmospheric ozone content, Q. J. R. Met. Soc., 96, 320-325, 1970.

Davidson, E. A., Fluxes of nitrous oxide and nitric oxide from terrestrial ecosystems, in Microbial Production and Consumption of Greenhouse Gases, edited by J. E. Rogers and W.B. Whitman, pp. 219-236, Am. Soc. Microbiol., Washington, D. C., 1991.

Dawson, R. N., and K. L. Murphy, The temperature dependency of biological denitrification, Water Res., 6, 71-83, 1972.

Deans, J. R., C. E. Clapp, J. A. E. Molina, K. S. Klair, M. J. Shaffer, and N. J. Durben, Maize dry matter production as related to biological nitrogen availability indexes, p. 119-130, in Proceedings of the International Symposium on Peat and Organic Matter in Agricuture, and Horticuture, 2nd, edited by K. M. Schallinger, Institute of Soils and Water, Bet Dagan, Israel, 1983.

Deans, J. R., J. A. E. Molina, and C. E. Clapp, Models for predicting potentially mineralizable nitrogen and decomposition rate constants, Soil Sci. Soc. Am. J., 50, 323-326, 1986.

Delwiche, C. C., Production and utilization of nitrous oxide by Pseudomonas denitrificants, J. Bacteriol., 77, 55-59, 1959.

Delwiche, C. C., The nitrogen cycle and nitrous oxide, in, Denitrification, Nitrification, and Atmospheric Nitrous Oxide, edited by C. C. Delwiche, John Wiley, New Yort, 1981.

De Vries, D. A., Heat transfer in soils, in Heat and Mass Transfer in the Biosphere, 1, Transfer Processes in the Plant Environment, edited by D. A. deVries and N. H. Afgan, John Wiley, New York, 1975.

Dunne, T., and L. Leopold, Water in Environmental Planning, W. H. Freeman, New York, 1978.

Duxbury, J. M., and P. K. McConnaughey, Effect of fertilizer source on denitrification and nitrous oxide emissions in a maize-field, Soil Sci. Soc. Am. J., 50, 644-648, 1986.

El-Haris, M. K., V. L. Cochran, L. F. Elliott, and D. F. Bezdicek, Effect of tillage, cropping, and fertilizer management on soil nitrogen mineralization potential, Soll Sci. Soc. Am. J., 47, 1157-1161, 1983.

Elkins, J. W. and R. Rossen, Summary Report 1988: Geophysical 
Monitoring for Climate Change, National Oceanic and Atmospheric Administration, Environmental Research Laboratory, Boulder, Colo., 1989.

Etheridge, D. M., G. I. Pearman, and F. de Silva, Atmospheric trace-gas variations as revealed by air trapped in an ice core from Law Dome, Antarctica, Ann. Glaciol., 10, 28-33, 1988.

Food and Agriculture Organization (FAO)/UNESCO, Soil map of the world 1:5000000, vol. I-X, Rome, 1971-1981.

Focht, D. D., The effect of temperature, $\mathrm{pH}$ and aeration on the production of nitrous oxide and gaseous nitrogen-A zero-order kinetic model, Soil Sci., 118, 173-179, 1974.

Focht, D. D., and W. Verstraete, Biochemical ecology of nitrification and denitrification, in Advances in Microbial Ecology, vol. 1, edited by M. Alexander, pp. 135-214, Plenum, New York, 1977.

Freney, J. R., J. R. Simpson, and O. T. Denmead, Ammonia volatilization, Ecol. Bull., 33, 291-302, 1981.

Frissel, M. J., and J. A. van Veen (Eds.), Simulation of Nitrogen Behavior of Soll-Plant Systems, p. 277, PUDOC, Wageningen, 1981.

Gardner, W. R., Movement of nitrogen in soil, Agronomy, 10, 550-572, 1965.

Gilliam, J. W., S. Dasberg, L. J. Lund, and D. D. Focht, Denitrification in four California soils: Effect of soil profile characteristics, Soil Sci. Soc. Am. J., 42, 61-66, 1978.

Gilmour, J. T., M. D. Clark, and G. C. Sigua, Estimating net nitrogen mineralization from carbon dioxide evolution, Soil Sci. Soc. Am. J., 49, 1398-1402, 1985.

Goodroad, L. L., and D. R. Keeney, Nitrous oxide emission from forest, marsh, and prairie ecosystems, J. Environ. Qual., 13, 448-452, 1984.

Grant, R. F., A technique for estimating denitrification rates at different soil temperatures, water contents, and nitrate concentrations, Soil Sci., 152, 41-52, 1991.

Griffin, G. F., and A. F. Laine, Nitrogen mineralization in soils previously amended with organic wastes, Agron. J., 75, 124-129, 1983.

Hadas, A., S. Feigenbaum, A. Feigin, and R. Portnoy, Distribution of nitrogen forms and availability indices in profiles of differently managed soil types, Soil Sci. Soc. Am. J., 50, 308-313, 1986.

Hartel, P. G., and M. Alexander, Effect of growth rate on the growth of bacteria in freshly moistened soil, Soil Sci. Am. J., 51, 93-96, 1987.

Hunt, H. W., A simulation model for decomposition in grasslands, Ecology, 58, 469-484, 1977.

Intergovernmental Panel on Climate Change (IPCC), Climate Change: The IPCC Scientific Assessment, edited by J. T. Houghton, G. J. Jenkins, and J. J. Ephraums, Cambridge University Press, New York, 1990.

Jager, G., and E. H. Bruins, Effect of repeated drying at different temperatures on soil organic matter decomposition and characteristics, and on the soil microflora, Soil Biol. Biochem., 7, 153-159, 1974.

Jansson, S. L., and J. Persson, Mineralization and immobilization of soil nitrogen, Agronomy, 22, 229-252, 1982.

Jenkinson, D. S., Studies on the decomposition of plant material in soil, V, The effect of plant cover and soil type on the loss of carbon from 14-C labeled ryegrass decomposing under field conditions, J. Soil Sci., 111, 64-70, 1977.

Johnsson, H., L. Klemedtsson, A. Nilsson, and B. Svensson, Simulation of field scale denitrification losses from soils under grass and barley, Plant Soil, 138, 287-302, 1991.

Jones, M., The organic matter content of the savanna soils of West Africa, Soil Sci., 24, 42-53, 1972.

Keeney, D. R., I. R. Fillery, and G. P. Marx, Effect of temperature on the gaseous nitrogen products of denitrification in a silt loam soil, Soil Sci. Soc. Am. J., 43, 1124-1128, 1979.

Khalil, M. A. K., and R. A. Rasmussen, Nitrous oxide: Trends and global mass balance over the last 3000 years, Ann. Glaciol., 10, 73-79, 1988.

Khan, M. F. A., and A. W. Moore, Denitrification capacity of some Alberta soils, Can. J. Soil Sci., 48, 89-91, 1968.

Klemedtsoon, L., B. H. Svensson, T. Lindberg, and T. Rosswall, The use of acetylene inhibition of nitrous oxjde reductase in quantifying denitrification in soils, Swed. J. Agric. Res., 7, 179-185, 1978.

Knapp, E. B., L. F. Elliott, and G. S. Campbell, Carbon, nitrogen and microbial biomass during the decomposition of wheat straw: A mechanistic simulation model, Soil Biol. Biochem., 15, 455-461, 1983.
Knowles, R., Denitrification, Ecol. Bull., 33, 315-329, 1981.

Leffelaar, P. A., and W. W. Wessel, Denitrification in a homogeneous, closed system: experiment and simulation, Soil Sci., 146, 335-349, 1988.

Letey, J., W. A. Jury, Aviva Hadas, and N. Valoras, Gas diffusion as a factor in laboratory incubation studies on denitrification, J. Environ. Qual., 9, 223-227, 1980.

Li, C., S. Frolking, and T. A. Frolking, A model of nitrous oxide evolution from soil driven by rainfall events, 2, Model applications, $J$. Geophys. Res., this issue.

McConnaughey, P. K., and D. R. Bouldin, Transient microsite models of denitrification, I, Model development, Soil Sci. Soc. Am. J., 49, 886$891,1985$.

McGill, W. B., H. W. Hunt, R. G. Woodmansee, and J. O. Reuss, Phoenix, a model of the dynamics of carbon and nitrogen in grasslandsoils, Ecol. Bull., 33, 49-115, 1981.

Mehran, M., and K. K. Tanji, Computer modeling of nitrogen transformations in soils, J. Environ. Qual., 3, 391-396, 1974.

Molina, J. A. E., C. E. Clapp, M. J. Shaffer, F. W. Chichester, and W. E. Larson, NCSOIL, a model of nitrogen and carbon transformations in soil: description, calibration, and behavior, Soil Sci. Soc. Am. J., 47, 8591, 1983.

Mosier, A. R., and W. J. Parton, Denitrification in a shortgrass prairie: a modeling approach, in Planetary Ecology, edited by D. Caldwell, T. Brierley, and C. Brierley, pp. 441-452, Van Nostrand Reinhold, Nuw York, 1985.

Mosier, A. R., W. D. Guenzi, and E. E. Schweizer, Soil losses of dinitrogen and nitrous oxide from irrigated crops in northeastern Colorado. Soil Sci. Soc. Am. J., 50, 344-348, 1986.

Mueller, M. M., V. Sundman, and J. Skujins, Denitrification in low $p H$ Spodosols and peats determined with the acetylene inhibition method, Appl. Environ. Microbiol., 40, 235-239, 1980.

Myers, R. J. K., and J. W. McGarity, Factors influencing high denitrifying activity in the subsoil of solodized solonetz, Plant Soil, 35, 145-160, 1971.

Nommik, H., Investigations on denitrification in soil, Acta Agric. Scand., 6, 195-228, 1956.

Nommik, H., Ammonium fixation and other reactions involving a nonenzymatic immobilization of mineral nitrogen in soil, Agronomy, 10 , 198-251, 1965.

Nyhan, J. W., Influence of soil temperature and water tension on the decomposition rates of carbon-14 labelled herbage, Soil Sci., 121, 288293, 1976.

Olson, R. A., The indispensable role of nitrogen in agricultural production, in National Conference on Management of Nitrogen in Irrigared Agriculture, edited by P. F. Pratt, US National Science Foundation, Environmental Protection Agency, University of California, Riverside, 1978.

Olson, R. A. and L. T. Kurtz, Crop nitrogen requirements, utilization, and fertilization, in Nitrogen in Agricultural Soils, Agron. Monog. 22, edited by F. J. Stevenson, American Society of Agronomy, Madison, Wis., 1982.

Parton, W .J., A. R. Mosier,, and D. S. Schimel, Rates and pathways of nitrous oxide production in a shortgrass steppe, Biogeochemistry, 6, 4558, 1988.

Paul, E. A., and N. G. Juma, Mineralization and immobilization of soil nitrogen by microorganisms, Ecol. Bull., 33, 179-195, 1981.

Paul, E. A., and J. A. Van Veen, The use of tracers to determine the dynamic nature of organic matter, Trans. Intl. Congr. Soil Sci., 11th, 3, 61-102, 1978.

Pearman, G. I., D. Etheridge, F. de Silva, P. J. Fraser, Evidence of changing concentrations of atmospheric $\mathrm{CO}_{2}, \mathrm{~N}_{2} \mathrm{O}$, and $\mathrm{CH}_{4}$ from air bubbles in Antarctic ice, Nature, 320, 248-250, 1986.

Pirt, S. J., The maintenance energy of bacteria in growing cultures, Proc. R. Soc. London, Ser. B., 163, 224-231, 1965.

Rodhe, H., A comparison of the contribution of various gases to the greenhouse effect, Science, 248, 1217-1219, 1990.

Rolston, D. E., M. Friled, and D. A. Goldhamer, Denitrification measured directly from nitrogen and nitrous oxide gas fluxes, Soil Sci. Soc. Am. J., 40, 259-266, 1976.

Roulier, M. H., and N. R. Fetter, Procedures for sampling and analysis of 
the atmosphere of field soils for trace amounts of nitrous oxide, Agron. Abstr., 7, 78-79, 1973.

Sahrawat, K. L., and D. R. Reeney, Nitrous oxide emission from soils, Adv. Soll Sci., 4, 103-148, 1986.

Sauerbeck, D. R., and M. A. Gonzalez, Field decomposition of carbon-14labelled plant residues in various soils of the Federal Republic of Germany and Costa Rica, in Symposium on Sall Organic Matter Studies, vol. 1, IAEA-FAO-211/18, 159-169, 1977.

Seiler W., and R. Conrad, Contribution of tropical ecosystems to the global budget of trace gases, especially $\mathrm{CH}_{4}, \mathrm{H}_{2}, \mathrm{CO}$, and $\mathrm{N}_{2} \mathrm{O}$, in The Geophysiology of Amazonia, edited by R. Dickinson, John Wiley, New York, 1987.

Sellers, W. D., Physical Climasology, University of Chicago Preas, Chicago, Ill., 1965.

Sexstone, A. J., T. B. Parkin, and J. M. Tiedie, Temporal response of soil denitrification rates to rainfall and irrigation, Soil Sci. Soc. Am. J., 49, 99-103, 1985.

Shah, D. B., and G. A. Coulman, Kinetics of nitrification and denitrification reactions, Biotechnol. Bioeng., 20, 43-72, 1978.

Smid, A. E., and E. G. Beauchamp, Effects of temperature and organic matter on denitrification in soil, Can. J. Soll Sci., 56, 385-391, 1976.

Smith, J. L., R. R. Schnabel, B. L. MoNeal, and G. S. Cambell, Potential errors in the first-order model for estimating soil nitrogen mineralization potentials, Soil Sci. Soc. Am. J., 44, 996-1000, 1980.

Smith, M. S., and J. M. Tiedje, Phases of denitrification following oxygen depletion in soil, Soll Biol. Biochem., J1, 261-267, 1979.

Sorensen, L. H., The influence of clay on the rate of decay of amino acid metabolites synthesized in soils during decomposition of cellulose, Soll Biol. Biochem., 7, 171-177, 1975.

Stanford, G., and S. J. Smith, Nitrogen mineralization potentials of soils, Soil Sct. Soc. Am. Proc., 36, 465-472, 1972.

Stanford, G., S. Dzienia, and R.A. Vanderpol, Effect of temperature on denitrification rate in soils, Soll Sci. Soc. Am. Proc., 39, 867-870, 1975.

Stevenson, F. J., Humus Chemistry, Genesis, Composition, Reactions, John Wiley, New York, 1982.

Tanji, K. K., Modeling of the soil nitrogen cycle, Agronomy, 22, 721-772, 1982.

Terry, R. B., R. L. Tate III, and J. M. Duxbury, Nitrous oxide emissions from drained, cultivated organic soils of South Florida, Air Pollut. Control Assoc., 31, 1173-1176, 1981.

Tiedje, J. M., Denitrification in soil, in Microbiology, edited by $\mathbf{D}$. Schlessinger, pp. 362-366, American Society of Microbiology, Washington D. C., 1978.

Tivy, J., Agricultural Ecology, Longman Scientific and Technical, Essex, U. K., 1990.

United States Department of Agriculture (USDA), Economic Research Service, Weather in U. S. Agriculture, edited by L. D. Siegen and F. Singer, Stat. Bull. 789, 1989.

United States Department of Agriculture (USDA), Soil Conservation Service, Soil survey laboratory data and descriptions for some soils of lowa, 1967.
Van Bavel, C. H. M., and R. Lascano, CONSERVB: A numerical method to compute soil water content and temperature profiles under a bare surface, Tech. Rep. RSC-134, pp. 1-73, Texas A\&M Univ., College Station, 1980.

Van Veen, J. A., and M. J. Frissel, Mathematical modelling of nitrogen transformations in soil, in Modelling Nitrogen From Farm Wastes, edited by J. F. K. Gasser, 133-157, Applied Science Publication Limited, London, 1979.

Van Veen, J. A., and M. J. Frissel, Simulation model of the behavior of $\mathbf{N}$ in soil, in Simulation of Nitrogen Behavior of Soll-Plant Systems, edited by M. J. Frissel and J. A. van Veen, pp. 126-144, PUDOC, Wageningen, 1981.

Van Verseveld, H. W., and A. H. Stouthamer, Growth yields and the efficiency of oxidative phosphorylation during autotrophic growth of Paracoccus denitrificans on methanol and formate, Arch. Microbiol., 118, 21-26, 1978.

Van Verseveld, H. W., E. M. Meijer, and A. H. Stouthamer, Energy conservation during nitrate respiration in Paracoccus denitrificens, Arch. Microbiol., 112, 17-23, 1977.

Watts, D. G., and R. J. Hanks, A soil-water-nitrogen model for irrigated com on sandy soils, Soil Sci. Soc. Am. J., 42, 492-499, 1978.

Weiss, R. F., The temporal and spatial distribution of tropospheric nitrous oxide, J. Geophys. Res., 86, 7185-7195, 1981.

Wijler, J., and C. C. Delwiche, Investigations on the denitrifying process in soil, Plant Soll, S, 155-169, 1954.

Wildung, R. E., T. R. Garland, and R. L. Buschbom, The interdependent effects of soil temperature and water content on soil respiration rate and plant root decomposition in arid grassland soils, Soil Biol. Blochem., 7, 373-378, 1975.

Wittamp, M., Decomposition of leaf litter in relation to environment, microflora and microbial respiration, Ecology, 47, 194-201, 1966.

Woldendorp, J. W., Nutrients in the rhizosphere, Agricultural yield potentials in continental climates, Proc. Coll. Intl. Potash Instinute, 16th, Bern, 99-125, 1981.

S. Frolking, Institute for the Study of Earth, Oceans, and Space, University of New Hampshire, Durham, NH 03824.

T. A. Frolking, Department of Geology and Geography, Denison University, Granville, OH 43023.

C. Li, The Bruce Company, 1100 6th Street, N.W., Suite 215, Washington, D. C. 20024.
(Received July 17, 1991;

revised February 27, 1992; accepted February 27, 1992.) 